Florida International University FIU Digital Commons

6-26-2013

\title{
Regional Diversification and Performance: Conceptualization and Competing Strategic Objectives
}

Keith James Kelley

Florida International University, kkello06@fiu.edu

DOI: $10.25148 /$ etd.FI13080906

Follow this and additional works at: https:// digitalcommons.fiu.edu/etd

Part of the Business Law, Public Responsibility, and Ethics Commons, International Business Commons, Other Business Commons, and the Strategic Management Policy Commons

\section{Recommended Citation}

Kelley, Keith James, "Regional Diversification and Performance: Conceptualization and Competing Strategic Objectives" (2013). FIU Electronic Theses and Dissertations. 935.

https://digitalcommons.fiu.edu/etd/935 


\title{
FLORIDA INTERNATIONAL UNIVERSITY
}

Miami, Florida

\section{REGIONAL DIVERSIFICATION AND PERFORMANCE: CONCEPTUALIZATION AND COMPETING STRATEGIC OBJECTIVES}

\author{
A dissertation submitted in partial fulfillment of the \\ requirements for the degree of \\ DOCTOR OF PHILOSOPHY \\ in \\ BUSINESS ADMINISTRATION
}

by

Keith James Kelley

2013 
To: Dean David Klock

College of Business Administration

This dissertation, written by Keith James Kelley, and entitled Regional Diversification and Performance: Conceptualization and Competing Strategic Objectives, having been approved in respect to style and intellectual content, is referred to you for judgment.

We have read this dissertation and recommend that it be approved.

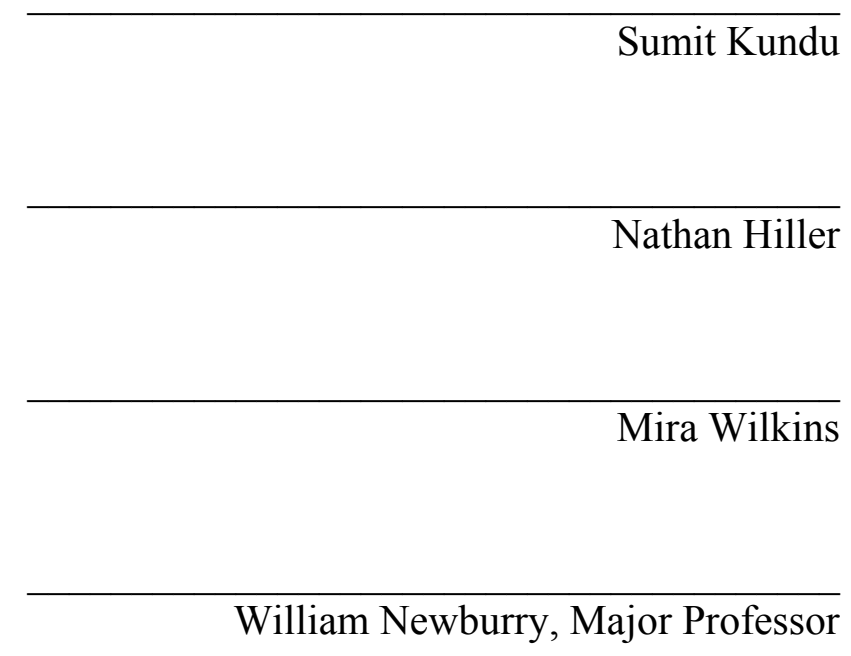

Date of Defense: June 26, 2013

The dissertation of Keith James Kelley is approved.

$\begin{array}{r}\text { Dean David Klock } \\ \text { College of Business Administration } \\ \hline \begin{array}{r}\text { Dean Lakshmi N. Reddi } \\ \text { University Graduate School }\end{array}\end{array}$

Florida International University, 2013 
(C) Copyright 2013 by Keith James Kelley

All rights reserved. 


\section{ACKNOWLEDGMENTS}

I wish to thank the members of my committee for their support and contributions to my work. Their direction has been most appreciated. Dr. Newburry in particular was helpful in guiding toward completion of this work. 


\section{ABSTRACT OF THE DISSERTATION \\ REGIONAL DIVERSIFICATION AND PERFORMANCE: CONCEPTUALIZATION \\ AND COMPETING STRATEGIC OBJECTIVES}

by

Keith James Kelley

Florida International University, 2013

Miami, Florida

\section{Professor William Newburry, Major Professor}

This dissertation comprised of three essays provides justification for the need to pursue research on multinationality and performance with a more fine-grained approach. Essay one is a conceptual response to an article written by Jean-Francois Hennart in 2011 which questions the need and approach toward future research in this domain. I argue that internalization theory does not render multinationality and performance research meaningless and identify key areas where methodological enhancements can be made to strengthen our research findings with regard to Hennart's call for more content validity. Essay two responds to the need for more-fine grained research on the consequences of multinationality by introducing non-traditional measures of performance such as social and environmental performance and adopting a more theoretically relevant construct of regionalization to capture international diversification levels of the firm. Using data from the world's largest 600 firms (based on sales) derived from Bloomberg and the Directory of Corporate Affiliates; I employ general estimating equation analysis to account for the auto-correlated nature of the panel data alongside multivariate regression techniques. Results indicate that regionalization has a positive relationship with economic 
performance while it has a negative relationship with environmental and social performance outcomes, often referred to as the "Triple Bottom-Line" performance. Essay three builds upon the work in the previous essays by linking the aforementioned performance variables and sample to corporate reputation which has been shown to be a beneficial strategic asset. Using Structural Equation Modeling I explore economic, environmental and social signals as mediators on relationship between regionalization and firm reputation. Results indicate that these variables partially mediate a positive relationship between regionalization and firm reputation. While regionalization positively affects the reputation building signal of economic performance, it aids in reputation building by reducing environmental and social disclosure effects which interestingly impact reputation negatively. In conclusion, the dissertation submits opportunities for future research and contributes to research by demonstrating that regionalization affects performance, but the effect varies in accordance with the performance criterion and context. In some cases, regional diversification may produce competing or conflicting outcomes among the potential strategic objectives of the firm. 


\section{TABLE OF CONTENTS}

CHAPTER

PAGE

I. A THEORETICAL ASSESSMENT OF THE EMPIRICAL LITERATURE ON THE IMPACT OF MULTINATIONALITY ON PERFORMANCE: A COMMENT........1

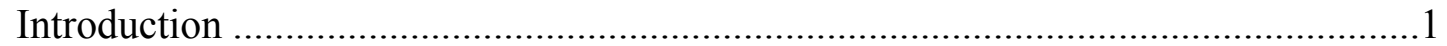

Transaction Cost Economics and Internalization in Multinationality........................ 6

Measurement of Multinationality ................................................................... 8

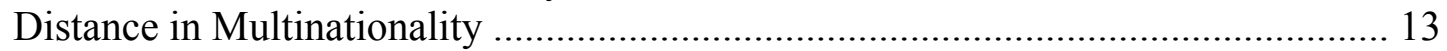

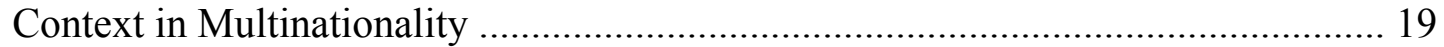

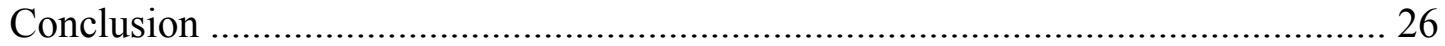

II. THE RELATIONSHIP BETWEEN REGIONALIZATION, INDUSTRY EFFICIENCY, AND ALTERNATIVE MEASURES OF PERFORMANCE..........28

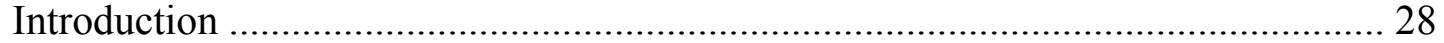

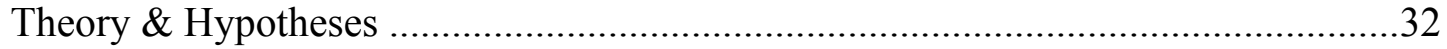

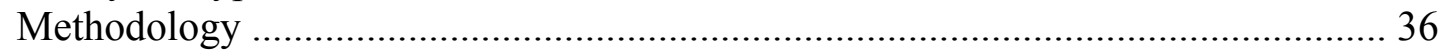

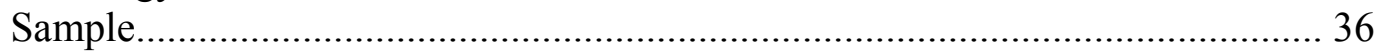

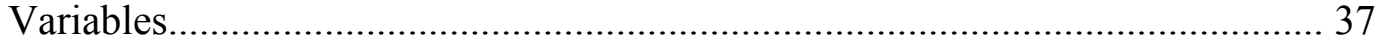

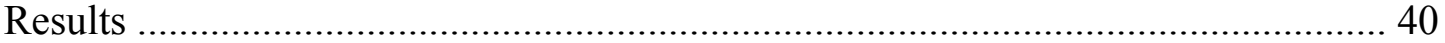

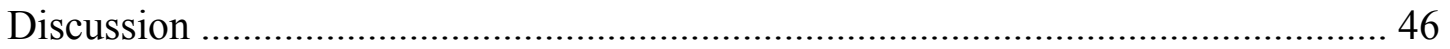

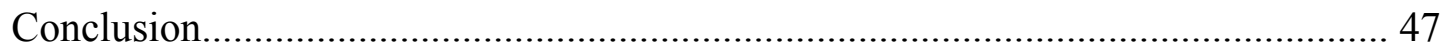

III. WHAT IS THE MEDIATING EFFECT OF 'TRIPLE BOTTOM-LINE' MEASURES OF FIRM PERFORMANCE ON FIRM REPUTATION? ..................48

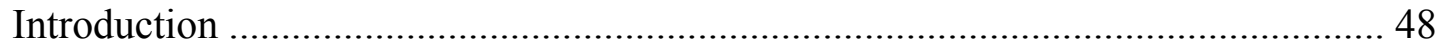

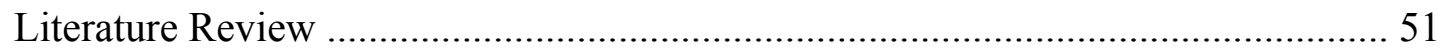

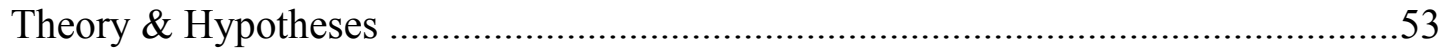

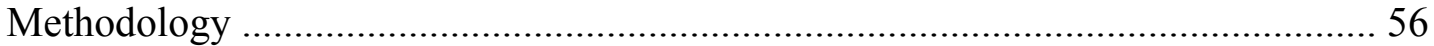

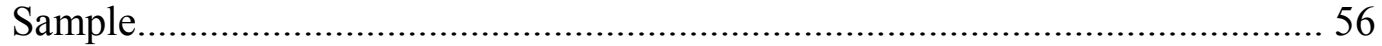

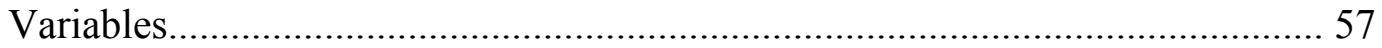

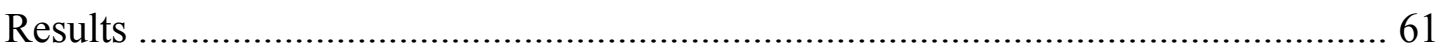

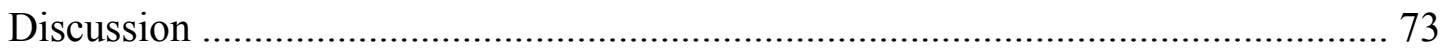

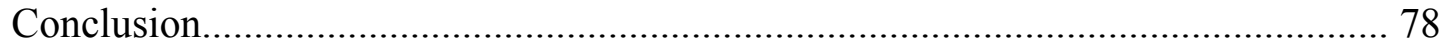

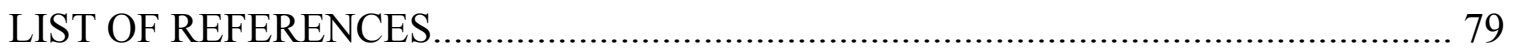

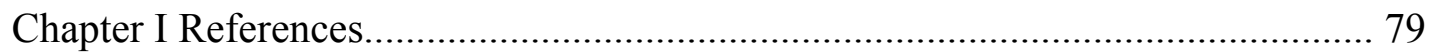

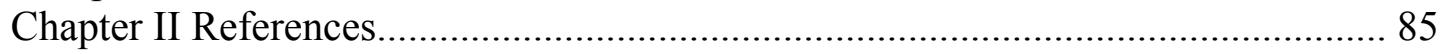

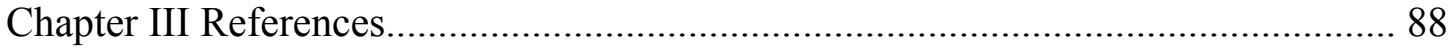

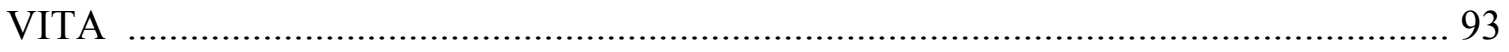




\section{LIST OF TABLES}

TABLE

PAGE

Table 1 Correlation Matrix with Significance Listed Beneath Standardized Coefficients. .41

Table 2 General Estimation Equation Clustering Company and Year Showing with Regression on Economic Performance. .42

Table 3 General Estimation Equation Clustering Company and Year Showing with Regression on Economic Performance and Industry Globalization Moderation.

Table 4 General Estimation Equation clustering company and year showing with regression on Environmental Performance.

Table 5 General Estimation Equation Clustering Company and Year Showing with Regression on Environmental Performance and Industry Globalization Moderation....44

Table 6 General Estimation Equation Clustering Company and Year Showing with Regression on Social Performance. 45

Table 7 General Estimation Equation Clustering Company and Year Showing with Regression on Social Performance and Industry Globalization Moderation. 45

Table 8 Showing Variable List of Means, Standard Deviations and Observations....... 62

Table 9 Matrix Showing Pairwise Variable Correlations............................. 63

Table 10 Base Model for Economic Signal Performance with Unstandardized Regression Weights and Significance Levels. .... .64

Table 11 Model for Economic Mediation with Unstandardized Regression Weights and Significance Levels 66

Table 12 Model fit indicators and Results of Difference Test Economic Mediation. 67

Table 13 Base Model for Environmental Signal Performance with Unstandardized Regression Weights and Significance Levels 67

Table 14 Base Model for Environmental Signal Performance with Unstandardized Regression Weights and Significance Levels

Table 15 Model Fit Indicators and Results of Difference Test Environmental Mediation 
Table 16 Showing Base Model for Social Signal Performance with Unstandardized Regression Weights and Significance Levels.......................................70

Table 17 Mediation Model for Environmental Signal Performance with Unstandardized Regression Weights and Significance Levels.......................................72

Table 18 Model Fit Indicators and Results of Difference Test Social Mediation.........72

Table 19 Full Base Model for Economic, Environmental, and Social Signal Performance with Unstandardized Regression Weights and Significance Levels.....................73

Table 20 Showing Mediation Full Model for Economic, Environmental, and Social Signal Performance with Unstandardized Regression Weights and Significance

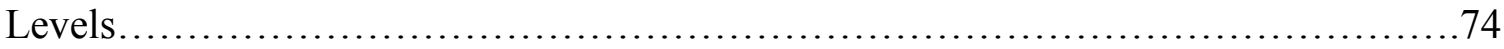

Table 21 Showing Model Fit Indicators and Results of Difference Test for Mediation in Full Model........................................................................ 75 


\section{LIST OF FIGURES}

FIGURE

PAGE

Figure 1 Global Versus Regional Efficiency Expressed as Distribution of Assets.........24

Figure 2 Global Versus Regional Efficiency Expressed as Distribution of Sales........... 25

Figure 3 Global versus Regional Efficiency of Firm-Specific Advantages.................... 26

Figure 4 Conceptual Model linking Regionalization Economic, Environmental and Social

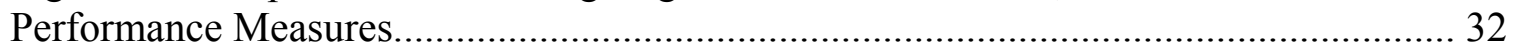

Figure 5 Conceptual Model of Mediation Effects 'Triple Bottom-Line' Measures on Relationship between Regionalization and Firm Reputation........................................ 51

Figure 6 The Base Path Model for Economic Signal Performance Using ROA and Standardized Regression Weights.

Figure 7 The Mediation Path Model for Economic Signal Performance Using ROA and Standardized Regression Weights..........................................................................65

Figure 8 The Base Path Model for Environmental Signal Performance Using ESG from Bloomberg and Standardized Regression Weights. .68

Figure 9 The Mediation Path Model for Environmental Signal Performance Using ESG from Bloomberg and Standardized Regression Weights. 68

Figure 10 The Base Path Model for Social Signal Performance Using ESG from Bloomberg and Standardized Regression Weights. .71

Figure 11 The Mediation Path Model for Social Signal Performance Using ESG from Bloomberg and Standardized Regression Weights. .71

Figure 12 The Mediation Path Full Model for Economic, Environmental, and Social Signal Performance Using ESG from Bloomberg and Standardized Regression Weights .74 


\section{A THEORETICAL ASSESSMENT OF THE EMPIRICAL LITERATURE ON THE IMPACT OF MULTINATIONALITY ON PERFORMANCE: A COMMENT}

\section{INTRODUCTION}

Recent research has made use of meta-analytic techniques to conclude that some of the spurious findings in multinationality and performance (MP) research is partially attributable to a number of moderating influences (e.g., R\&D intensity, advertising intensity, product diversification, country of origin, industry, and firm age and size, inter alia; see Bausch \& Krist, 2007; Kirca and colleagues, 2011; Tihanyi, Griffith, \& Russell, 2005; Yang \& Driffield, 2012) The evidence suggests that multinationality is related to performance but future research should adopt a contingency-perspective, employing more fine-grained research techniques and subsequently conveying results with a narrower scope of external validity. While future research will undoubtedly adopt improved methodologies, a recent pair of articles by Hennart $(2007 ; 2011)$ questions whether or not MP research adds any value beyond such traditional theories as transaction cost economics and internalization (TCI). Alongside questioning the significance of MP research, these articles and others have also addressed the broader methodological issue, which is that many scholars do not adequately craft a construct of multinationality to match their arguments (Hennart, 2007; 2011; Ramaswamy, Kroeck, \& Renforth, 1996). The latter concern may also be related to the value of future research on multinationality and performance when considering its theoretical underpinnings in reference to TCI. Thus, in this study we seek to comment on Hennart's (2011) arguments surrounding the value of future MP research in consideration of internalization theory, various dimensions 
of multinationality, and in so doing provide insight into solving some methodological challenges surrounding optimal fit of a firm's foreign 'footprint' (i.e., multinationality).

Internalization theory when applied to internationalization focuses on two interdependent decisions, where to locate foreign operations and what mode of entry, or control, to employ (Buckley \& Casson, 1976; 1998). One interpretation of internalization theory suggests that differences between nations are not an issue for multinationals as they are already accounted for in the decisions of where to go abroad and how best to operate in the foreign market. In other words, market imperfections may lead to firmbased solutions (Buckley \& Casson, 1998; Coase, 1937), and these imperfections that may exist are considered before multinationals go abroad. Thus, it can be argued that the only reason to suspect multinationality would affect performance is when a firm is not at its optimum level or 'fit' of multinationality (Hennart, 2011). Furthermore, there are two main reasons why a firm may not exist at its optimal level of multinationality; the first being its slow adjustment to the optimum-level and the second being its unwillingness to adjust its foreign footprint (e.g., executive hubris, bounded rationality, or other discretionary barriers) (Hennart, 2011). While these arguments are well founded, they present a paradox by discounting the value of MP research and simultaneously illustrating that when a firm is not at its optimal mutlinationality level, performance will be affected negatively. Therefore, multinationality can affect performance, at least negatively, when it deviates from the optimum level. While this is a rather one-sided logic in that over or under-internationalized firms' performance will be affected negatively, when considering standardized levels multinationality, expressed as 
deviations from the optimum, increasing or decreasing a firm's multinationality toward the optimum will be positively related to its performance.

We do not suggest in this paper that the proper measurement of multinationality, or degree of internationalization (DOI), has not been a significant source of debate in the MP literature or has been entirely overlooked (see Ramaswamy, Kroeck, \& Renforth, 1996; Sullivan, 1994; Thomas \& Eden, 2004, Wiersema \& Bowen, 2011). Sullivan (1994) argues that the widely used measure of Foreign Sales as a Percent of Total Sales (FSTS), similarly operationalized in the emerging literature on regionalization (e.g., Rugman \& Verbeke, 2004; 2007; Rugman \& Oh, 2010), is insufficient to capture the full extent of multinationality. This is an opinion increasingly shared by other scholars (e.g. Stevens \& Bird, 2004; Thomas \& Eden, 2004; Hennart, 2011). Yet, Ramaswamy and colleagues (1996) illustrate, citing psychometric and methodological issues as well as validity concerns, how the development of a multidimensional index of DOI isn't necessarily more accurate or appropriate than previously utilized uni-dimensional items. Indeed, Ramaswamy and colleagues (1996) argue that "the usefulness of the index, (DOI), ultimately depends on its ability to assist in predicting criteria of interest (pg. 174)", and "any index must be firmly rooted in theory (pg. 175)." Thus, while there are many scholars who recognize that internationalization is multidimensional in nature (Rugman \& Oh, 2010; Sullivan, 1994; Thomas \& Eden, 2004), international business and strategy scholars should only employ those dimensions of internationalization that are meaningful to answering their specific research question (Hennart, 2011; Ramaswamy et al, 1996). 
Hennart (2011) suggests that alongside capturing three distinct dimensions that may fully account for multinationality (foreign market penetration, foreign production presence, and country scope) as proposed by Sullivan (1994) and Thomas and Eden (2004), there is a fourth implicit-dimension which is the degree of diversity of foreign markets, that also helps measure its foreign footprint. This fourth dimension of distance is frequently employed in theoretical development and hypotheses, particularly when applying the internalization and transaction cost frameworks, but rarely captured by the multinationality construct in a manner consistent with the argument. For instance, Sullivan (1994) operationalizes the psychic dispersion element of his attitudinal component by measuring the geographic dispersion of overseas subsidiaries (Sullivan \& Bauerschmidt, 1990); thus capturing an aspect of distance, but not fully discriminating among different types of distance or how each may impact the criterion of interest. Country environment diversity can be measured by cultural, political, and economic differences (i.e. distances), inter alia, and they been shown to significantly moderate the relationship between international asset dispersion and economic performance (Goerzen \& Beamish, 2003). Thus, as many scholars employ aspects of cultural, institutional, and geographic distance formally (e.g., Kogut \& Singh, 1988; Kostova \& Zaheer, 1999; Thomas \& Eden, 2004), frequently building upon internalization theory (Buckley \& Casson, 1976), the implicit use of distance in MP research warrants a closer examination and possible marriage with the multinationality construct.

The aforementioned studies echo the sentiment argument that distance matters (Ghemewat, 2001). However, not only does the type of distance (Cultural, Administrative, Geographic, and Economic) matter, in terms of its impact on 
international commerce, but also its effect will vary in accordance with the industry or products being considered (Ghemewat, 2001). Indeed, the Tihanyi et al. (2005) metaanalysis revealed that the relationship between cultural distance and international diversification is significantly moderated by type of industry. As many of the benefits of multinationality accrue to larger firms, often times operating across multiple industries, both academics and practitioners will gain valuable insight for corporate-level diversification strategies when considering the role of distance with respect to industry, in MP research. Accordingly, we focus attention in the remainder of our paper on several issues brought to light in the Hennart (2011) article: "A theoretical assessment of the empirical literature on the impact of multinationality on performance". First, whether or not the underlying mechanisms behind transaction cost/internalization theory are sufficient to account for all the variance otherwise attributable to multinationality rendering such studies meaningless. Second, we address one the most conspicuously absent, or latent, components in the measurement of multinationality, which is the effect of distance. In so doing, we will examine how distance fits in the measurement of multinationality in relief of other previously addressed dimensions and in relation to internalization theory. Third, we will explore how using alternative dimensions of distance, and in turn different regional classifications will moderate the MP relationship. Last, we will argue that other contextualized circumstances help determine the role of distance in the MP relationship and exploration of the regional versus global efficient nature of industries is a good place to start. 


\section{TRANSACTION COST ECONOMICS AND INTERNALIZATION IN}

\section{MULTINATIONALITY}

Buckley and Casson (1976) viewed the firm as "an internalized bundle of resources which can be allocated between product groups and between national markets". Moreover, internalization focuses on two interdependent decisions, where to locate foreign operations and what mode of entry, or control, to employ (Buckley \& Casson, 1976; 1998). These decisions are contingent upon a main tenet of internalization theory and transaction cost economics (TCI)( Coase, 1937; Hennart, 1982; 2007; Williamson, 1975) which is that market imperfections will lead to more efficient firm-based solutions rather than less-efficient market-based ones (Buckley \& Casson, 1998). Although originally conceived in to explain the boundaries of the firm (Coase, 1937) in a domestic sense, internalization also supports the argument that differences between national markets, and therefore the limited market-based solutions they present, increase the need for firm-based solutions. Conversely, when markets are sufficiently developed on the price system alone, hierarchical organization of activities is less likely (Hennart, 2007).

Kogut and Zander (1993) argue that the firm provides a more efficient mechanism for the internal transfer of resources such as tacit knowledge, irrespective of market failures; therefore presence of market imperfections would only serve to strengthen this relationship. Indeed, Kostova (1999) and Kostova and Roth (2002) argue that socioinstitutional distance is a major factor inhibiting the transfer of strategic practices across national boundaries. The extent to which internalization occurs is therefore relative to 1) the extent that market imperfections exist and 2) the degree to which the transfer of strategic assets or resources is done more efficiently with firm-based solutions. 
Rugman $(1985 ; 1986)$ argues that ownership-advantages (O) must be internalized (I) to be effective (so that they do not dissipate) in international markets, and therefore, Dunning's OLI paradigm (1981) may be reduced to just internalization and location (L). Consequently, internalization theory is paradoxical when considering distance as liability generating in that the multinational, specific to the transfer of firm-specific assets, already accounts for it with location and entry mode decisions (Buckley \& Casson, 1976; 1998). At its core, internalization implies that firms choose the least cost location for each activity that they perform and that firms will internalize in markets up to the point that the benefits no longer outweigh the costs (Buckley, 1988; Kirca et al. 2011). Moreover, this fundamental assumption implies, ceteris paribus, that the relationship between multinationality and performance would be purely positive and at most a curvilinear relationship reflecting diminishing returns, or the achievement of minimum efficient scale (Hennart, 2007). This assumes, however, that decisions of location and entry mode are made rationally, that those conditions under which they are made do not change and are congruent with the parent's ownership-strategy (Gatignon \& Anderson, 1988; Stopford \& Wells, 1972). Furthermore, Kostova (1999) and Kostova and Zaheer (1999) would likely argue that the transfer of strategic organizational practices across national boundaries, and the legitimacy they hold across national boundaries, do not remain constant over time. Indeed, many assumptions upon which TCI arguments are made (e.g., rationality and economic efficiency), do not closely approximate real world conditions. Thus, we suggest that while TCI theory is very powerful in explaining firm behavior (transactions), both in a domestic and an international sense, it is also a rather isolated and inertial theory with limited ability to explain irrationality and constraints placed on 
decision makers, influence of industry structure conditions, rapid changes in external market conditions, and path dependency in firm growth. While the underlying principles of TCI may account for a great deal of the variance explained in MP research, its limitations are manifest in the inconsistent research findings. Furthermore, the argument that the only reason multinationality will affect performance is when an MNC does not have a fit based upon its internal resources, and beyond the assumptions of internalization theory as put forth by Hennart (2011), simultaneously rationalizes the need for MP research as firms are rarely optimized.

\section{MEASUREMENT OF MULTINATIONALITY}

\section{Spurious Results}

Early research on multinationality often examined a supposed linear relationship with firm performance of various types (e.g. ROI, ROS, ROA, Sales Growth, Asset Turnover, Stock Returns, etc....). Some research demonstrated a positive linear relationship (Vernon, 1971; Grant, Jammine, \& Thomas, 1988), other research a negative linear relationship (Sidharthan and Lall, 1982; Michel \& Shaked, 1986), and still other work no relationship whatsoever (Morck \& Yeung, 1991). Perhaps as a result of the nature of these inconsistencies, beginning in the late 1980's scholars examined the possibility that curvilinear U-shaped relationships (Qian, 1997; Ruigrok and Wagner, 2002), inverted U-shaped relationships (Geringer, Beamish and daCosta, 1989; Hitt, Hoskisson, \& Kim, 1997; Gomes \& Ramaswamy, 1999), or even three-stage cubic relationships (Contractor, Kundu, \& Hsu, 2003) may exist. Many of these studies included extraneous conditions under which the relationship might change such as the 
dependent variables of performance, whether or not the firm was product diversified, the stage of international expansion, or asset specificity among others.

Consequently, in an effort to reconcile and build upon all previous MP research, scholars have recently employed meta-analytic techniques to confirm the significance of such moderating effects as R\&D intensity, advertising intensity, industry differences, criterion variables employed, and the measurement of multinationality itself (Kirca et al., 2011; Yang \& Driffield, 2012). Yet despite the recognition of these moderating influences, scholars seem rather determined to ignore the fact that how multinationality is measured has yet to be universally agreed upon (Verbeke \& Brugman, 2009), but perhaps more importantly, that not having consensus is methodologically appropriate. Indeed, scholars acknowledge that multinationality may have multiple dimensions such as: 1) foreign market penetration-frequently captured by a firms total foreign sales, 2) foreign production-often noted by foreign assets or employees and the production of goods and services, 3) country scope-generally measured by the number of foreign countries in which the firm operates, and 4) the degree of diversity of the foreign markets where a firm operates, looking at the geographic dispersion or psychic dispersion of countries in which the firm operates (Hennart, 2011; Sullivan, 1994; Thomas \& Eden, 2004). However, more often than not, the problem isn't simply a matter of capturing the full dimensionality of the construct, but rather selecting the correct dimensions and method for the research question to be answered correctly (Hennart, 2007; Ramaswamy et al., 1996).

Foreign market penetration is frequently employed in MP research and captured by measuring firm's foreign sales as a percent of total sales (FSTS). This measure is one 
of the most widely adopted measures of multinationality, or degree of internationalization, first employed by Vernon (1971). Unfortunately, this does not readily distinguish between sales by foreign direct investment operations and simple exports and of course makes no distinction between number of countries or any number of differences, or distances, between markets. While many of the arguments surrounding the effects of multinationality lay squarely on the differences firms face when operating abroad, suggesting that such foreign operations are likely more complicated and risky than domestic operations, this measure is highly inaccurate.

Foreign production is also often employed and denoted by foreign assets or employees and the production of goods and services. Vernon (1971) shows that his 187 multinationals, which generally have a higher degree of international content activity by comparison to all U.S. enterprises, also outperform the rest of the U.S. enterprises on the aforementioned criterion variables of ROS and ROA. Thus, what Vernon (1971) actually found was that those 187 enterprises he classified as multinationals had higher performance than those not classified as multinationals; yet this multinationality was determined by whether or not a company was operating, or had previously operated, manufacturing subsidiaries in six or more countries. Similarly, Wilkins (1970) qualified multinationality as a firm having production in two or more countries. This production criterion was originally how multinationals were defined and further established that multinationality isn't simply defined by sales in a foreign location but instead by valueadding content activity or production (Osterberg \& Ajami, 1971). Unfortunately, multinationality must also recognize the purpose for this production as sometimes locations are used in the intermediate product market, whereby sales may occur only 
slightly or not at all in the foreign production location (Dunning, 2009). The foreign location of production is rendered significant often times when considering its distance from the home market in that if the foreign location is quite different than the home market, the location may be only used for its comparative advantages in input factors (i.e. cheap labor, access to raw materials).

Country scope generally measures the number of foreign countries in which the firm operates. This variable is susceptible to issues surrounding distance as the scope of operations implies that operating in more and more countries somehow will affect performance. Of course this further implies that increasing a firm's amount of international operations adds to the complexity of operations, in turn taxing the cognitive limitations of managers (Hill \& Hoskisson, 1987) or the transfer of strategic organizational practices (Collinson \& Rugman, 2008, Kostova \& Zaheer, 1999). The logic in this variable dimension is built upon handling businesses in multiple locations, which are assumed to be different. However, when capturing regional activities of multinationals, Rugman \& Verbeke (2007) include not only foreign subsidies as being within the region, but also domestic. The arguments set forth in this manner of classification by Rugman and Verbeke rest upon the notion that firms need similar markets in which to exploit their firm-specific assets, and markets within the region, even when foreign, are not much different than domestic. Thus, when applying a scope of countries dimensions, there is an underlying assumption that foreign countries are sufficiently different than domestic as to render scope of operations in domestic setting irrelevant to the argument. Scope is only relevant as a multinationality dimension if it carries some aspect of country differences to distinguish it from firm scope in any other 
manner such as number of subsidiaries in their home market or perhaps business/product diversification.

Degree of diversity of the foreign markets captures the geographic dispersion or psychic dispersion of countries of operation. While Hennart's (2011) proposed fourth dimension of multinationality ${ }^{1}$ implies an aspect of distance by arguing that the differences or diversity between foreign markets will affect performance and therefore should be accounted for, it does not necessarily suggest techniques for capturing it, instead referencing approaches by Goerzen \& Beamish (2003). Goerzen and Beamish (2003) introduce the country environment diversity variable in which they capture differences along the following dimensions: 1) Economic Conditions, 2) Global Competitiveness, 3) Political Conditions, and 4) Cultural Diversity using entropy measures. Yet, while Goerzen and Beamish (2003) introduce an aspect of distance employing a country environment diversity variable, alongside the international asset dispersion, they do not consider them part of the same unidimensional construct of geographic scope (multinationality) despite the high correlation (.60). Instead, employing entropic techniques of Hitt, Hoskisson, and Kim (1997) for both the asset dispersion and country diversity variables (which also employed hierarchical clustering techniques), Goerzen and Beamish (2003) show that foreign market diversity moderates the relationship between international asset dispersion and economic performance, suggesting that distances (i.e. political, economic, and cultural differences) do play a significant role in the multinationality and performance relationship. Outside attenuating

\footnotetext{
${ }^{1}$ In the 2011 Global Strategy Journal article Hennart introduces it as a fourth dimension (pg. 136) and later outlines it as dimension (5) alongside the additional dimension (3) of foreign sales dispersion as part of five dimensions accounting for a firms total foreign 'footprint'.
} 
the likely influence of an additional dimension of diversity, or distance, in the conclusions drawn from research on multinationality and performance, the Goerzen and Beamish (2003) paper illustrates that the geographic configuration of a firm will likely impact its economic performance and there may be multiple relevant measures of distance.

\section{DISTANCE IN MULTINATIONALITY}

There is a growing debate among scholars as to whether or not firms follow global or regional (Dunning, 1995; Friedman, 2005; Rugman, 2000; Rugman \& Verbeke, 2004) paths to international expansion. Research has already emerged surrounding the effect of this new notion of regionalization or regional diversification on the classic exploration of multinationality and performance $(M P)$ (Qian, Khoury, Peng, \& Qian, 2010; Qian, Li, Li, \& Qian, 2008; Rugman \& Oh, 2010). Rugman (2000) felt it essential to recognize that multinationals were not global but in fact regional in their activities, building upon the "Triad" classification introduced by Ohmae (1985), and asserting the need for distinction which is based almost entirely on the spatial proximity of foreign investments (i.e. distance from the home-market). For the purposes of this paper, we define spatial proximity as "similarity or homogeneity along one or more dimensions of distance that warrant the clustering or grouping together of countries to form regions". This definition is born from the logic employed by such scholars such as Hitt et al. (1997) and Goerzen and Beamish (2003) who employed clustering techniques and regional classifications to measure diversification or diversity, and more directly Ohmae's Triad classification (1985) which contends that there are three main regions in the world that share a number of commonalities beyond simple geography (e.g. slow macro-economic 
growth, protectionist pressures, technological infrastructure, and industries with capital and knowledge-intensive firms). Moreover, as the notion of regional diversity or regionalization and performance has grown in importance (Qian et al., 2008; Qian et al., 2010; Rugman \& Oh, 2010) there is a great need to explore the delineations of spatial proximity. Indeed, how we define spatial dimensions, or distance, and the regions generated from them, may affect any research findings we report (Berry, Guillen, \& Zhou, 2010; Flores \& Aguilera, 2007).

Although early studies explored internationalization and performance, this construct gave way to international diversification, or multinationality, and performance studies. Yet before any solid conclusions could be drawn from original MP studies, and before globalization became a construct in international business research surrounding performance outcomes, Rugman (2000) pointed out firms were mainly regional in their international scope. The work examining the 'regional nature' of multinationals was furthered by Rugman and Verbeke (2004) and Collinson and Rugman (2008) among others and also gave rise to studies examining the relationship between regionalization and regional diversification and firm performance (Rugman and Oh, 2010; Qian, Li, Li, \& Qian, 2008; Qian, Khoury, Peng, and Qian, 2010). Accordingly, distinguishing this new construct from past constructs, or perhaps reconciling the two based upon the underlying aspect of distance, seems of vital importance before there is another wave of spurious research findings. In bringing forth the distinctions between prior constructs measuring international foreign content activity and firm performance, and the more recent construct of regionalization, perhaps a clearer picture of previously confounded nuances will be revealed. 
When describing the internationalization process, in connection with his Product Life Cycle Theory, Vernon $(1966 ; 1971)$ suggested that firms will first export products to foreign locations that have similar attributes that can affect consumption habits. In other words, consumers in foreign markets with similar amounts of purchasing power and having similar needs or wants will be the first to request imported products in great abundance, and sufficient amount of demand in exports would warrant production expansion in that foreign market. Similarly, Johanson and Vahnle (1977) argued that this process of international expansion was incremental and based upon experience and learning, an internationalization process that begins with export to markets similar to the home market. Many theories of (FDI) contend that firms must seek out foreign markets where they can exploit their ownership advantages in such a way as to overcome the 'liability of foreignness' or the 'cost of doing business abroad' (Hymer, 1976; Dunning, 1977, Zaheer, 1995), which in all likelihood means host-markets cannot be extremely dissimilar from the home-market. Indeed, Kenichi Ohmae (1985) contends in his work "Triad Power: The Coming Shape of Global Competition" that there are three main regions in the world, that share a number of commonalities (e.g. slow macro-economic growth, protectionist pressures, technological infrastructure, and industries with capital and knowledge-intensive firms): North America, Europe, and Japan. Furthermore, Ohmae (1985) argued that few companies have been able to replicate the level of their home-region performance in the other two regions, a problem which he referred to as a global impasse. Only a handful of firms such as IBM, Coca-Cola, Sony, Philips alongside five others (Rugman \& Verbeke, 2007), might aptly be described as a "Triad Power" or in other words, firms that have had indiscriminant success in deployment of 
their firm-specific advantages in all markets. Dunning $(1993 ; 1995)$ in describing the phenomenon of globalization, suggested that technologies and international agreements were 'shrinking the world' and allowing countries to participate in international commerce where previously they could not. Yet, Rugman $(2000 ; 2004)$ argues that globalization is largely an illusion and that most transnational corporations are more aptly characterized as regional in nature and not global because they have a large portion of their activities within these 'Triads' regions. Rugman and Verbeke (2004; 2007) and Rugman (2004) use a method to capture a firm's regionalization that is very similar to the commonly accepted measure of internationalization FS/TS, in that regionalization is the amount of Sales within the Region (RS) divided by Total Sales in the Whole World (RS/TS). This method of capturing foreign content activity, employed by Rugman and Verbeke (2004; 2007) and Yip, Rugman and Kudina (2007), takes into account both sales by subsidiaries as well as exports to the Rest of Region (ROR) and Rest of World (ROW). Rugman and Oh (2010), while acknowledging the confusion surrounding the construct of multinationality, ultimately use their regional measure in place of multinationality to test the S-curve relationship (Contractor et al., 2003; Lu \& Beamish, 2004). Rugman and Oh (2010) harshly continue to criticize what they call a scope (metric) count of multinationality, referring to these attempts to capture breadth of internationalization as invalid. The authors then refer to the entropy measures put forth by Errunza and Senbet (1984) and Hitt and colleagues (1997) that weight the averages of diversification across heterogeneous geographic locations, as being more appropriate. Qian et al. (2008) apply the entropy measure to examine regional diversification, applying a more fine-grained 19-region classification scheme by the World Bank, and 
finding a curvilinear, inverted u-shaped relationship similar to that found in previous research on multinationality and performance (see Geringer et al., 1989; Gomes and Ramaswamy, 1999.) Building on earlier work, Qian and colleagues (2010) apply an intraversus inter-regional diversification effect model, following the four-region classification scheme employed by Hitt and colleagues (1997) and the entropy measures that include not only subsidiary location, but also the weight of sales activity within the region. They find a positive relationship between intra-regional diversification and performance. Qian and colleagues (2010) find that there is a curvilinear relationship between inter-regional diversification and performance, where firms with moderate levels of inter-regional diversification have the highest levels of performance. What is evident in both the work by Rugman and colleagues and the work by Qian and colleagues is that the constructs of regionalization or intra-regional diversification imply international content in similar countries and there is a positive relationship between this type of expansion and performance. On the other hand, inter-regional diversification, which is when there is investment in more than one region, parallels the multinationality and international diversification findings in that moderation is the key to solid performance. Furthermore, the work by Qian and colleagues (2008) and Qian and colleagues (2010) illustrate the fact that regions may be classified differently and that the correlational relationship of diversification across regions, rather than within regions, is not linear. Thus, it seems obvious that how regions are classified and how the level of foreign content activity is captured within regions will greatly affect any results associated with future regionalization and performance research. 
Recognizing that how regions are defined may vary in accordance with both scholars' arguments, and the constraints placed on them by data availability, is not necessarily new. Ronen and Shenkar (1985) suggested that clustering nations on attitudinal dimensions, recognizing that geography, languages, and religion are interrelated, is the most accurate and optimal way to cluster countries into regions. They, Ronen and Shenkar (1985), argued that eight clusters of nations existed along the following nomenclature: a Latin American, Latin European, Far Eastern, Near Eastern, Arab, Anglo, Germanic, and Nordic. Ohmae (1985) introduced his notion of "Triads" which separated the world into three main regions; North America, Europe, and Japan, and this was expected to grow into another fourth region deemed 'other' to include proximal markets to the original three. Hitt and colleagues (1997), although claiming to measure international diversification, use a regional-entropic measure, due to a lack of sales data at the country-level. Hitt and colleagues reason that Ohmae (1985), and Morrison and Roth (1992), are right to believe firms are more frequently competing in regional battles, and thus adopt the COMPUSTAT classification scheme with the following regions: Africa, Asia and Pacific, Europe, and the Americas. This latter clustering scheme could be thought of as a managerial, or a firm-level, view of regions which is derived by Hitt and colleagues (1997) from data reported by COMPUSTAT in accordance with how sales are reported in Annual Reports of each firm. Berry (2006) creates two regional groupings of nations associated with levels of economic development: developing and advanced. Qian and colleagues (2008) adopt the more parsimonious clustering of nations determined by the World Bank (1995), also involving a criterion based on economic development, but including such additional factors as 
institutions, political risk, and intellectual property protection. Although there are some clear patterns with respect to North America (specifically the US and Canada) and Europe, which have a strong geographic concentration, when scholars attempt to form additional regions or clusters of nations, there is a great deal of theoretical and practical division in research. Ronen and Shenkar (1985) recognize that geography, languages, and religion are all interrelated. Similarly, Ohmae (1985), Rugman and Verbeke (2007), and Collinson and Rugman (2008), argue that regions are classified by some homogeneous characteristics that also influence a firm's ability to exploit its firm-specific advantages (FSAs) inter-regionally, essentially limiting the number of "Triad Power" or bi-regional firms that exist. Consequently, geography is and will remain a central theme in the classification of regions. Yet the fact that firms internationalize for numerous reasons associated with their abilities and needs in relation to their firm and other nations of the world makes how managers or firms classify regions, and differences in such dimensions as: attitude, economic development, culture, geo-political orientation, legal traditions, and other institutions (Ronen \& Shenkar, 1985; Vaaler, Aguilera, Ghemewat, 2001; Flores, 2007; Hitt et al., 1997, Flores \& Aguilera; 2007), relevant variables in the prediction of firm outcomes.

\section{CONTEXT IN MULTINATIONALITY}

Hennart (2011) asserts, building largely on Internalization Theory (Buckley \& Casson, 1976; Hennart, 1982), that multinationality itself should not necessarily contribute to a firm's economic performance as each firm, in a rational setting, would adjust to the optimal level of multinationality. Furthermore, economic performance would only be affected in cases where firms were under or over the optimal level, which 
may be attributable to managerial decisions (Hennart, 2011), but has also been shown to exist systematically in certain industries (Birkinshaw, Morrison, \& Hood, 1995). Indeed, while managers make decisions about which countries to enter, and effectively the firm's level of multinationality, their 'discretion' in choice is constrained by multilevel factors including their task environment (Finkelstein, Hambrick \& Cannella, 2009). Although the importance of industry structure on firm strategy may wax and wane over time (Hoskisson, Hitt, Wan, \& Yiu, 1999), industrial organization (I/O) scholars have long noted its importance to firm outcomes and actions (Bain, 1956, Caves \& Porter, 1977; Porter, 1980).

With respect to 'global' industries, Bikinshaw et al. (1995) identify three broad characteristics identified by scholars (see Porter, 1980; Hout, Porter, \& Rudden, 1982; Kogut, 1991) that act as structural determinants for 'global' industries: (1) the opportunity for economies of scale in value added activities; (2) differences in comparative advantages between nations; and (3) standardized demand across national markets. Therefore, some industries' structural determinants warrant greater global integration strategies while others less, affecting the under or over globalized firm's performance in kind. This lead Birkinshaw et al. (1995: 649) to state that, "the nature of the relationship between global integration and performance may vary substantially from one industry to another".

The variety of multilevel differences that exist between industries has been well documented in the last 60 or more years of research, particularly in the domain of strategic management (Bain; 1956; Birkinshaw et al., 1995; Caves \& Porter, 1977; Chandler, 1962; Hill, Hitt, \& Hoskisson, 1992; Markides \& Williamson, Porter; 1994; 
1980; Rumelt, 1974; Wiersema \& Bowen, 2008). While I/O economics can be traced to Bain's (1956) influential work on industry concentration, the Structure (of Industry)Conduct (of Firm)-Performance (of Firm) (S-C-P) paradigm, began receiving a great deal more attention during the late 1970's and 1980's with work on industrial barriers to mobility (Caves \& Porter, 1977) as well as structural determinants or forces influential to the firm's success developed by Michael Porter (1979; 1980). Chandler's (1962) Strategy \& Structure largely introduced the notion of the multidivisional form (M-Form) organization which served as a foundation for understanding diversification strategies attributable to coordinating different types of related and unrelated industries for financial and scope economies (Rumelt, 1974; Hill et al., 1992), effectively classifying industries by a firm's internal ability to exploit resources across them. Moreover, Chandler's (1962) work served as a foundation for later scholars seeking to understand and explain a firm's behavior based upon transaction cost efficiencies (e.g., related and unrelated diversification, vertical integration) (Buckley \& Casson, 1976; Hennart, 1982, Rugman, 1981; Wlliamson, 1975). Thus, there is also a great deal of attention placed on the pressures and determinants of value-added global integration that vary from one industry to the next (Birkinshaw et al., 1995; Wiersema \& Bowen, 2008) and may moderate a relationship which is otherwise expected to have no correlation (Hennart, 2011).

Understanding that firms go abroad in order to exploit efficiencies based on their internal resources (Buckley \& Casson, 1976; Hennart, 1982; Rugman, 1981) as well as in response to competitive actions of other firms (Knickerbocker, 1973; Wiersema \& Bowen, 2008) illustrates the fact the global integration strategies are essential to performance and these are not always optimal in relation to the industry, or the firm. 
Contractor et al. (2003) provide evidence that service firms in general may pass through three stages of multinationality in an attempt to reach the optimal 'fit'. In stage 1, firms have yet to achieve sufficient economies of scale or are still learning to overcome liabilities of foreignness and so performance is negative. Stage 2 firms begin reaping the many transaction cost efficiency benefits such as economies of scope, financial economies or other comparative advantages which create positive economic performance. In stage 3 , firms begin trending toward negative performance again as diseconomies of scale, and scope, emerge from coordination of activities across too many different, sometimes peripheral markets. Furthermore, the authors show that differences between service industries' characteristics (e.g., capital-intensive or knowledge-based) can alter this negative-positive-negative (cubic) relationship (Contractor et al., 2003). Thus, there appears to be a strong industry-based influence on multinationality and performance which is tied to the optimal balance between transaction cost type efficiencies achieved and the influence of liabilities of foreignness or cultural distance, inter alia.

Rugman and Oh (2007: 39) arrange roughly 16 broad categories of industries into two larger categories that are manufacturing and services in their examination of the regional nature of multinationals of the Global 500 firms. In these broad categories they show that both the sales (84.2\%) and the assets of service firms (83.8\%) have a tendency to be more regional, whereas manufacturing is also regional in sales (64.6\%) and assets (68.9\%), but significantly less so than the service multinationals overall. These numbers reflect a particular regional classification scheme known as the "Triad" regions of North America, Asia, and Europe, adapted from Ohmae's (1985) classification with commonalities beyond simple geography (e.g., slow macro-economic growth, 
protectionist pressures, technological infrastructure, and industries with capital and knowledge-intensive firms and consequently). Thus, it is no surprise that firms whose services are developed specifically for consumer groups, and require more intimate knowledge of those target markets to succeed, would have sales mainly in their home region. Indeed, Collinson and Rugman (2008) argue that firm specific advantages are in part determined by local conditions, which is why firms cannot exploit them very well outside their home region. Thus, opportunities for achieving scope and scale-based efficiencies are restricted by the diminished value of services to consumers in increasingly distant markets. Service firms may also find that value-added production activities are increasingly difficult away from the home-region due to the nature of service firms themselves, which often require customer involvement in production (Boddewyn et al., 1986).

Manufacturing firms on the other hand do not necessarily need to produce for their local markets as they are not bound by one frequently defining characteristic of service firms, the simultaneity of production and consumption (Boddewyn et al., 1986). Furthermore, manufacturing firms are more likely to take advantage of scale and scopebased efficiencies, as well as cost advantages associated with country arbitrage in factors of production (e.g., labor, raw materials, tax rates), beyond their home regions. Yet it isn't necessarily the distinction between services and manufacturing that defines the level of regional or global efficiencies so much as it is the nature of the product or service in relation to the end consumer. In other words, products or services may warrant a more regional scope in their multinational activity if the benefits of global integration exceed the costs of proximity to the end consumer. Accordingly, we broadly categorize 
industries based upon their 'global' or 'regional' efficiency which serves to capture the consumer's role in the customization of the product or service as well as the possible restrictions of local market conditions on the firm's ability to generate economic rent. As a result of this distinction, not all industries that may be thought of as manufacturing have purely global efficiency and not all service firms have regional efficiency (See Figures 1 and 2):

Figure 1 Global Versus Regional Efficiency Expressed as Distribution of Assets

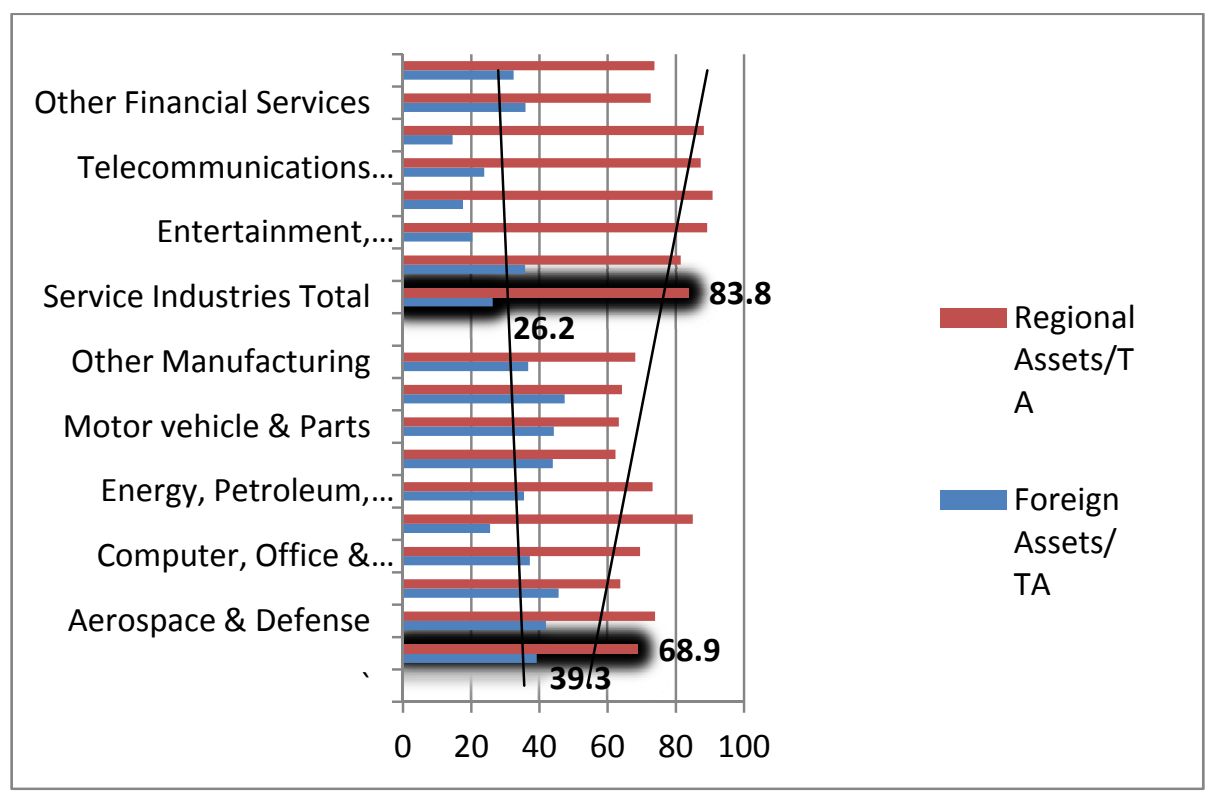

*Adapted from Rugman \& OH (2007), in Research in Global Strategic Management; Regional Aspects of Multinationality and Performance, Vol. 13, edited by Alan Rugman, Elsevier. 
Figure 2 Global Versus Regional Efficiency Expressed as Distribution of Sales

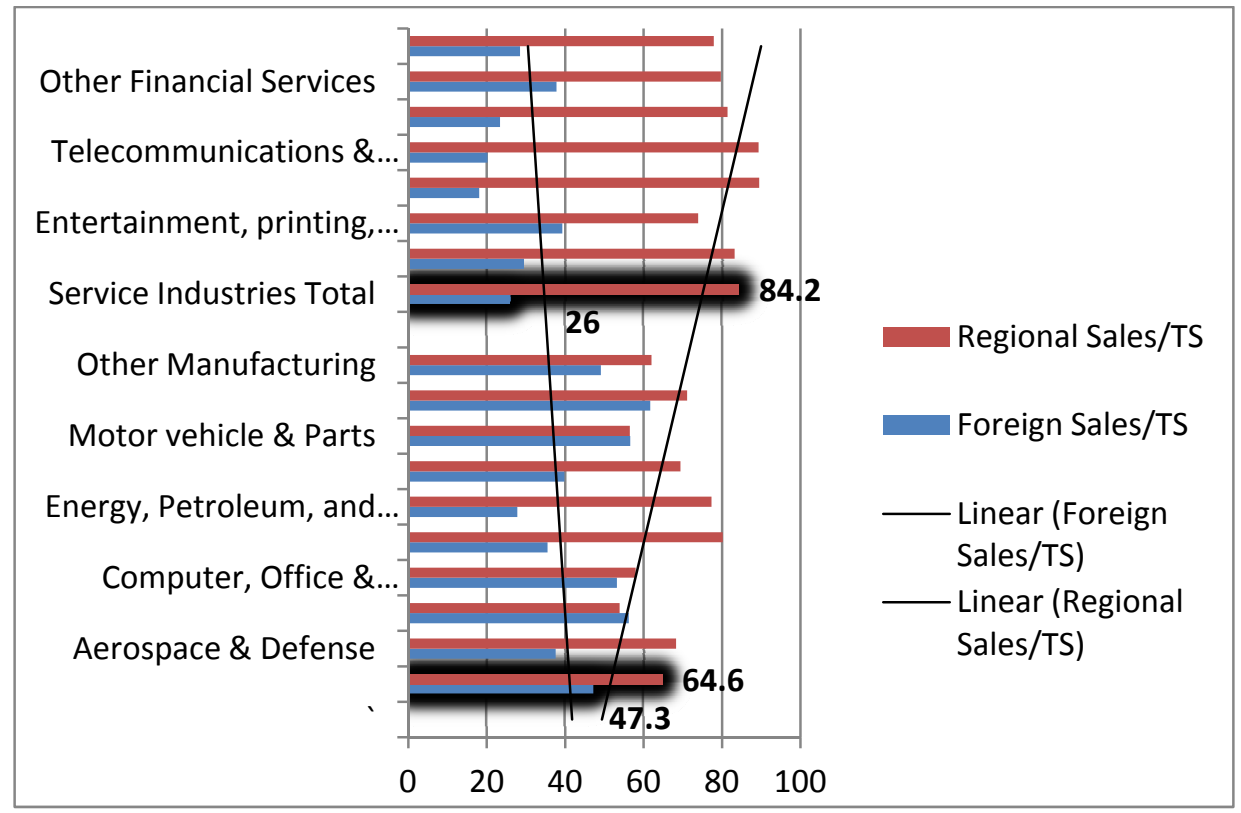

*Adapted from Rugman \& OH (2007), in Research in Global Strategic Management; Regional Aspects of Multinationality and Performance, Vol. 13, edited by Alan Rugman, Elsevier.

This scope of an industry's multinationality, in terms of being regionally or global efficient, might therefore be described as 'how efficient firms are, in a particular industry, at leveraging the scope of their value-added activities in markets within and without their home region'. Thus, some industries will be populated with firms with a limited ability to create value from their sales and production activities outside the home region. On the other hand, some industries will be populated by firms that are not only more able to create value from their sales and production activities outside the home region, but may also rely on the inputs or outputs (i.e. low-cost factors of production, scale economies for standardized products) in order to be more efficient. As illustrated below in Figure 2, firm-specific advantages (FSAs) are created and central to all firms' success, but in 
regionally efficient industries, sales and production efforts are restricted by challenging conditions outside the home region, whereas the opposite is true in global efficient industries.

Figure 3 Global versus Regional Efficiency of Firm-Specific Advantages.

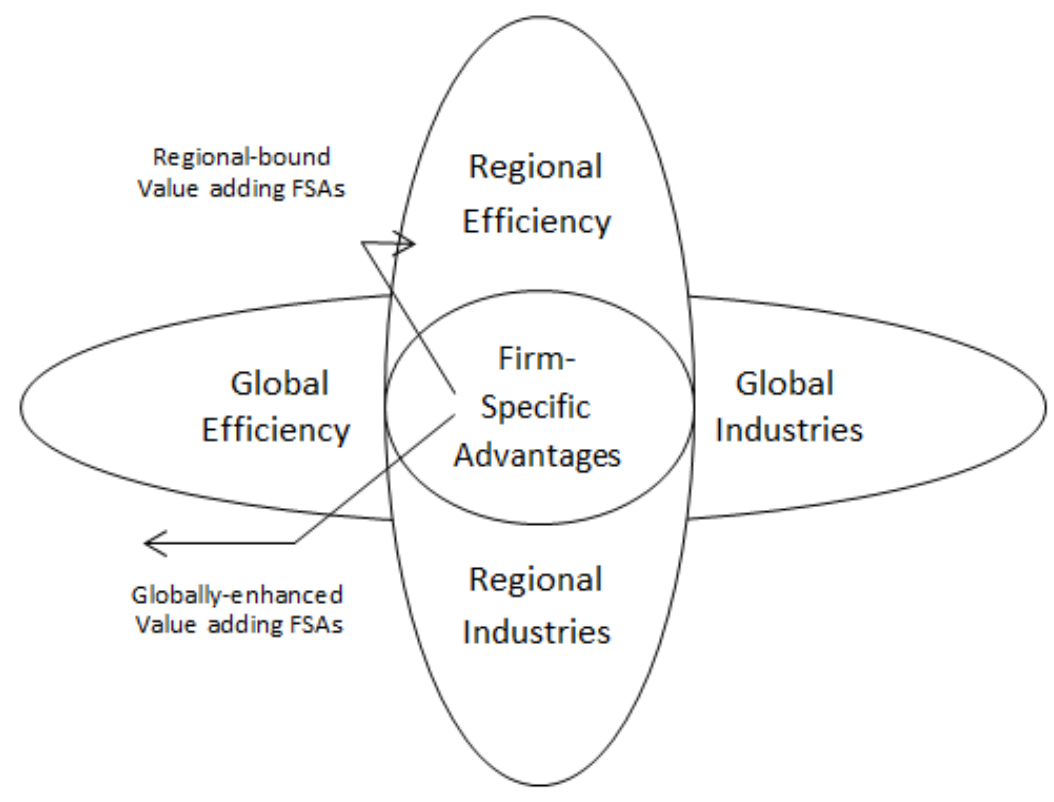

\section{CONCLUSION}

While I agree with Hennart's assertion that one of the most pervasive problems in multinationality and performance research is content validity I disagree with some of his recommendations which will correct for it. I also disagree with his belief that internalization theory renders multinationality and performance research meaningless and point out that his recognition that decision makers are boundedly rational, is evidence that mistakes may be made during any international transaction. The sum of the these transactions, were they always perfectly rational and constant over time would perhaps diminish any broad relationships that might exist between multinationality and 
performance, but they are never perfectly ration and the effect not constant over time. Thus, the sum of these transactions may represent the sum of errors in decision making which can lead to unexpectedly negative or positive outcomes. The more uncertainty that surrounds a particular decision, the more likely there is to be an error suggesting that differences between markets must be a methodologically relevant component of multinationality measurement.

Thus, distance must be incorporated in the measurement of multinationality, and when it is, the adoption of a regionalism construct is perhaps most appropriate. In addition, the various dimensions of distance that may be used when attempting to define regions, and therefore regionalism, must not be theoretically confounded as each dimension is likely to impact firm outcomes and performance differently. The regionalism construct in light of a variety of industries, most likely defined by integration characteristics or efficiency, will also help explain why the effect on performance will vary from one industry to the next. 
THE RELATIONSHIP BETWEEN REGIONALIZATION, INDUSTRY EFFICIENCY, AND ALTERNATIVE MEASURES OF PERFORMANCE.

\section{INTRODUCTION}

Over the past several decades, the search for the precise relationship between multinationality and performance (MP) in MNEs has been the pseudo 'Holy Grail' for international business scholars. Fortunately, scholars have come to accept that the MP relationship is subject to a number of contingencies such as the extent or stage of multinational expansion (Contractor, Kundu, \& Kim, 2003; Hitt, Hoskisson, \& Kim, 1997; Lu \& Beamish, 2004), the MNE's level of product diversification (Hitt et al., 1997, Tallman \& Li, 1996), or firm-specific assets such as advertising or R\&D intensity (Kirka et al., 2011, Lu \& Beamish, 2004) inter alia. Unfortunately, scholars have yet to come to any agreement on an exact term, or construct, to describe multinationality, often using it interchangeably with such terms as international diversification, degree of internationalization (DOI), or even globalization among others. The latter term was criticized by Rugman (2000) who demonstrated that although many identify multinationals as the catalysts of global integration, $90 \%$ of the stock of their FDI is regional and thus regionalism or regionalization is a more apt description of their activity. This finding is supported by the notion that firm-specific advantages (FSAs) are developed in accordance with home market country and industry conditions which in turn diminishes their exploitative value the further away from the home region the firm operates (Collinson \& Rugman, 2008; Rugman \& Verbeke, 2007). However, in some industries, value is created through comparative efficiencies such as cheaper factors of 
production (e.g. labor; land; raw materials), driving firms to search out opportunities in distant markets where labor laws and working conditions may be more relaxed or perhaps environmental regulation less strict. Indeed, Birkinshaw, Morrison, and Hood (1995: 649) state that; "the nature of the relationship between global integration and performance may vary substantially from one industry to another". Thus, as scholars begin to broadly explore such constructs as regional diversity on firm performance (Qian, Khoury, Peng, \& Qian, 2010; Qian, Li, Li, \& Qian, 2008), there is a great need to explore both the impact of industry differences as well as alternative measures of performance (e.g. social, environmental) in addition to those accounting and market-based measures frequently employed .

Global strategy and international business researchers recognize that a variety of methodological idiosyncrasies alter the exact relationship between multinationality and performance (Kirka et al., 2011; Tallman \& Li, 1996; Yang \& Driffield, 2012), though some suggest that most variance is explained by efficiencies associated with internalization theory (Hennart, 2011). Hennart (2011) suggests that if multinationality affects performance, it does so only in circumstances where firms deviate from the optimum level of multinationality, leaving one relevant question to be answered: why do firms deviate from the optimal level of multinationality? While some scholars attribute most strategic outcomes (e.g. performance of the firms) to managers and other internal resources of the firm such as knowledge or strategic leadership (Barney, 1991; Kogut \& Zander; 1993), the importance of managers' decisions on firm outcomes is long-debated among strategy scholars, many of whom have foundations in industrial organization economics (I/O). IO scholars also recognize the constraints placed on managers and their 
decisions (i.e. conduct), as a result of industry-specific conditions (i.e. structure) (Canella, Finkelstein, \& Hambrick; 2009; Hoskisson, Hitt, Wan, \& Yiu, 1999; Porter, 1981), which serve as vital elements in the Structure-Conduct-Performance S-C-P paradigm often attributed to Bain (1956) and Mason (1939) and used for strategic analysis. Consequently, any future research surrounding regionalization and firm performance should examine how industry may affect a firm's ability to optimize its performance. Furthermore, the effect should be examined through an internalization lens such that the industries may be classified in accordance with their reliance upon regional or perhaps global efficiencies to create value.

The performance element of the S-C-P is sometimes interpreted as individual firm performance, or instead otherwise as overall industry performance, a construct distinction upon which strategic analysis and findings may be contingent. Similarly, research has recently shown that findings in MP research are effected by the choice of performance indicators, accounting-based (e.g., ROS, ROA, etc.) or market-based (e.g., market capitalization/Tobin's Q) (Yang \& Driffield, 2012). Yang and Driffield (2012) argue that accounting-based measures capture short-term performance whereas market-based indicators capture a company's valuation by the public and are better measures of longterm performance. Strategy scholars place a great deal of interest on accounting-based measures of performance, following the Friedman (1970) doctrine which famously argued that the only "social responsibility of business is to increase its profits", as long as it plays within the 'rules of the game'. Yet, this view is deemed inadequate by some (Chakravarthy, 1986; Elkington, 1998; 2004), as multiple stakeholders often apply different criteria when evaluating corporate performance (Freeman, 1984). 
Indeed, performance on "Triple Bottom-line" performance measures (e.g. economic, social, environmental), which can be thought of as a reflection of a firm's ability to meet societal norms (Fombrun \& Shanley, 1990), enhance a firm's reputation by appealing to multiple stakeholders. Thus, the issue of pleasing multiple stakeholders, and therefore creating a solid reputation in countries of operation, is an increasingly important consideration for competitive strategy building that leads to sustained financial performance (Barney, 1991; Roberts \& Dowling, 2002). As firms expand internationally, many pursuing regional strategies to reduce complexity that hinders performance (Qian et al., 2008; Hill \& Hoskisson, 1987), the question of how firms fair on alternative measures of performance becomes of great strategic consequence.

This research attempts to address two issues surrounding emerging research on regionalization and performance: 1) does the choice of performance variable (e.g. economic, social, and environmental) alter the relationship; and 2) are these relationships in turn moderated by industry characteristics (see Figure 4)? The remainder of this study will include a section for theory and hypothesis development followed by a conceptual model, a section on the proposed methodological approach (i.e. sample, variables, statistical method) and progress toward full empirical analysis, alongside a small conclusion on practical and academic contributions of the proposed study. 
Figure 4 Conceptual Model linking Regionalization Economic, Environmental and Social Performance Measures

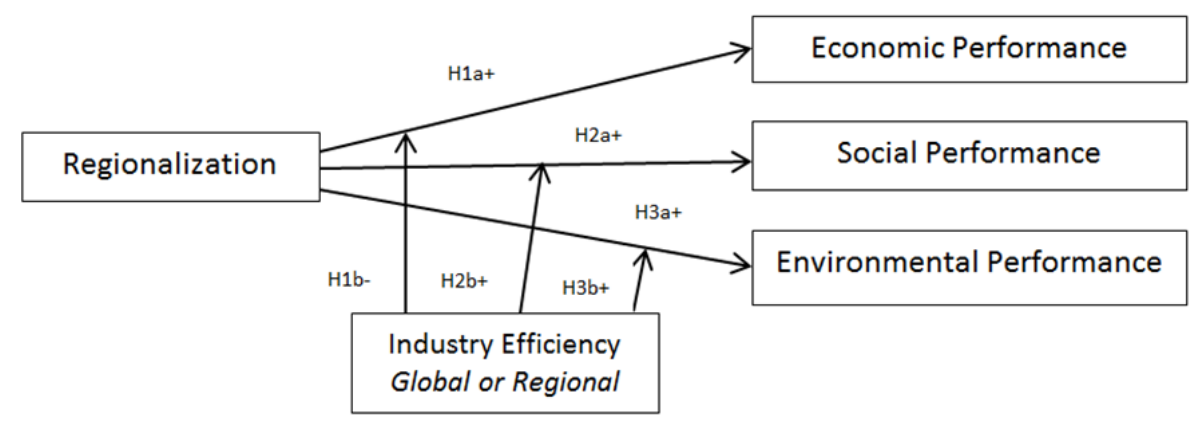

THEORY \& HYPOTHESES

Ohmae (1985) argued that firms were unlikely to become "Triad" powers due to the fact they create sources of competitive advantage based upon conditions in their home region. Consequently, firms are rarely able to exploit their firm-specific advantages in more than one region, let alone all three major regions around the world. Rugman (2000) furthered this argument by suggesting firms were not 'global' as many suggested during the 1990s, but instead 'regional' or perhaps 'bi-regional' (Rugman \& Verbeke, 2007). Firms create and exploit value based upon regional market conditions, yielding 'liabilities of regional foreignness' to firms hoping to exploit their FSAs outside the home region (Rugman and Verbeke, 2007). Collinson and Rugman (2008) find that Japanese firms are regional in nature as a result of this condition and Qian and colleagues (2010) find that too much inter-regional diversification hinders economic performance. Thus, it is apparent that a firm's ability to achieve economic rent from its international operations has diminishing returns the further it operates outside its home region leading us to propose the following; 
H1a. Regionalization is positively related to a firm's economic performance.

Ohmae (1985) and Rugman \& Verbeke (2007) do recognize that some firms are able to compete effectively around the globe (e.g. Coca-Cola, IBM) as their value propositions may cross-borders more effectively. Indeed, industries in which firms do not require significant cultural adaptation or whose products serve universal needs may increase their economic performance as a result of their ability to increase efficiencies based on scale and scope economies across the globe. While Rugman and Verbeke (2007) often focus on sales as the primary determinant of its regional nature, global strategy scholars have long-recognized that MNCs also capitalize on comparative advantages between nations in factors of production (e.g. cheap labor, raw materials) (Birkinshaw et al, 1995; Dunning, 2009) leading some MNCs to seek ever increasing efficiencies based upon cost arbitrage in distant markets leading us to propose the following;

H1b. The relationship between regionalization and economic performance is moderated by an industry's efficiency configuration such that the relationship becomes weaker in industries whose value is based upon global efficiency configuration rather than regional efficiency configurations.

King and Shaver (2001) show that production of waste increases as the complexity of managing multiple jurisdictions is increased. Product stewardship, that 
could be attributed to green supply chain management initiatives, also diminishes as collaboration between buyers and suppliers diminishes (Vachon \& Klassen, 2006), a likely outcome of communication complexity in international supply chain management (Prater, Biehl, \& Smith, 2001). From a resource-based perspective, environmental performance and profitability are linked as higher environmental performance leads to the creation of intangible assets such as reputation (Hall, 1992; Russo \& Fouts, 1997). Thus, it appears regionalization increases the likelihood of developing sustainable practices by reducing the complexity of operating across multiple markets leading us to propose the following;

H2a. Regionalization is negatively related to a firm's environmental performance.

Unfortunately, these differences in production methods between developed regions, and developing regions with 'low cost production methods and less stringent regulations', are often what leads developed nation firms to source manufacturing abroad (Haugh \& Talwar, 2010; Bansal; 2005). Consequently, in industries driven by value creation by exploiting lower standards in distant market, keeping the sourcing of material and production more regional is likely more environmentally friendly, but perhaps more economically costly, leading us to propose the following;

H2b. The relationship between regionalization and environmental performance is moderated by an industry's efficiency configuration such that the relationship 
becomes stronger in industries with value based upon global efficiency configurations rather than regional efficiency configurations.

The transfer of organizational practices, and the desire to maintain legitimacy, becomes more difficult as the distance between subsidiary operations from the home country increases (Kostova, 1999; Kostova \& Zaheer, 1999). Indeed, embedding sustainable practices that will lead to higher social performance may be impeded by such things as: priority levels of various stakeholders and constraints on corporate executives across national boundaries (Schneper \& Guillen, 2004), the number of employees qualified to train others in socially responsible behaviors, the resources a company possesses to pay for such training (Haugh \& Talwar, 2010), and changes in the external environments related to economic conditions or governmental and nongovernmental pressures (Campbell, 2007; Haugh \& Talmar, 2010). As the three main regions of the world as conceived by Ohmae (1985) share a number of commonalities beyond simple geography (e.g. slow macro-economic growth, protectionist pressures, technological infrastructure, and industries with capital and knowledge-intensive firms), firms operating in environments outside the home region are likely to encounter more difficulty in their community and labor relations leading us to propose the following:

H3a. Regionalization is negatively related to a firm's social performance.

Dunning (2009) notes that location, and locational efficiencies, is a rather neglected factor in international business research that had profound implications on 
strategic configuration and performance. Indeed, firms do not always operate in foreign markets and seek to maintain the same standards or working conditions or other factors of production they use in their home region. Instead, they seek cost advantages attributable to weak labor market regulations and standards. Indeed, firms whose value proposition is based upon generating efficiency by producing in distant markets are likely to have much lower social performance. Conversely, if industries base their value on global efficiency and are too regional, they are likely to perform better on social measures leading us to propose the following;

H3b. The relationship between regionalization and social performance is moderated by an industries efficiency configuration such that the relationship becomes stronger in industries with value based upon global efficiency configurations rather than regional efficiency configurations.

\section{METHODOLOGY}

Sample:

Our sample was based on the Reputation Institute's annual study of the world's largest 600 firms (based on sales) from 2006-2011. Data for these companies was then merged from the Directory of Corporate Affiliates (DCA) and Bloomberg using period years 2004-2011 which allowed for lagging of the regionalization construct by T-1 years (i.e., company-year 2006 dependent variable may be predicted by company-year 2005 value of regionalization). Beginning with 3600 potential observations by company-year (6 years * 600 companies), the data set is reduced to 2971 observations through variation 
in the world's 600 largest companies during the period of 2006-2011(i.e., some firms join the list and others fall off) and availability of data at the subsidiary and other levels (a majority of missing sample data was from firms in emerging markets - e.g. China). An additional 23 independent and outlying observations were deleted when significant abnormal deviation from the variable range was detected. Such deletions included the 2008 AIG report of $-14 \%$ return on equity resulting from losses totaling nearly $\$ 62$ Billion, isolated incidences of severe negative return on assets (e.g. Delta Airlines), and in one case a negative value in goodwill reported by a company from Thailand. Due to the nature of our argument surrounding international operations, and the difficulties in managing across regions, several firms with a very low number of employees (less than 500) were also omitted. The final sample size by company-year without missing variables was 1465 . The roughly $51 \%$ reduction from company year observations is largely a result of availability of environmental and social variables. A larger sample was available for tests of mediation with respect to economic signals and is reported in the results.

\section{Dependent Variables:}

There are three dependent variables to be employed in separate models and simultaneously in multivariate analysis. We use the Bloomberg financial database, which aggregates corporate social performance to include both items related to environmental performance, as well as items regarding community and labor relations (Muller \& Kolk, 2010).

Economic Signals - There are several measures available as potential signals of economic performance. Return on sales is a widely used measure and helps avoid the 
potential bias in total assets between service and manufacturing firms; however, sales may vary significantly from year to year creating inconsistent results. Return on equity is an often employed measure yet does not adequately reflect the international nature and varying ownership structure found in our sample. Thus, we employ the firm's Return on Assets (ROA) given by Bloomberg. Service firms may also possess significant and recordable amounts of assets suitable for comparison to manufacturing firms. In addition, assets are more stable than sales year on year and also reflect a more closely aligned operationalization of economic signaling given the use of foreign subsidiaries in our regionalization variable.

Environmental Signals - Environmental Disclosure scores, theoretical range of 0 to $100 \%$ where $100 \%$ indicates greatest disclosure, take from Bloomberg which also takes into account industry. This variable includes quantifiable indicators such as total carbon emissions, renewable energy credits as a percent of revenues, waste and water consumption per employee, and as well qualitative indicators such as third party environmental assessment, green building policies, and green supply chain management policies.

Social Signals - Social Disclosure scores which have a theoretical range of 0 to $100 \%$ where $100 \%$ indicates greatest disclosure, take from Bloomberg which also takes into account industry. This variable includes quantifiable indicators such as lost time for accidents and training per employee, and as well qualitative indicators like community spending as a percent of pre-tax profit (if greater than $1 \%$ then yes), and policies on health, fair remuneration, equal opportunity and human rights. 


\section{Independent Variables:}

Regionalization - Hennart (2011) identifies the use of inappropriate multinationality constructs, whereby the theory researchers build their hypotheses on is incongruent with the operationalization of multinationality, as a rampant methodological problem in MP research. Researchers have shown that how multinationality is measured in many cases using regions for diversification measurement, or how regions are defined; affects the findings on firm outcomes such as locational choice and performance (Flores \& Aguilera, 2007). Rugman and Oh (2010) employ the commonly used ratio technique examining regional sales to total sales RSTS, with their adapted "Triad" regional classification created by Ohmae (1985). Qian and colleagues (2010) apply similar alternative classification based upon economic development and follow entropy techniques similar to Hitt and collegues (1997). We employ a degree of regionalization measure calculated as the percentage of subsidiaries located in the MNCs' home region. We follow the Flores and Aguilera (2007) classification approach using the UN distinctions of 23 regions. This value ranged from 0 to 1 and was lagged T-1 years. This approach is most closely in line with our arguments surrounding disclosures which would be mainly attributable to operational activities rather than sales alone. The UN classification scheme involving 23 regions is also the most parsimonious and aptly recognizes regional idiosyncrasies better than other more broad classifications employed by Hitt and colleagues (1997) or Rugman and Oh (2010) with 4 and 3 regions respectively. 


\section{Control Variables -}

Firm industry - Dichotomous for service firms and 0 for manufacturing following Rugman \& Oh, (2005) these are shown to be regional or global in their asset orientation.

Economic Crisis - Dichotomous 0 for years 2006-2007; 2010 and 1 for years 2008-2009

Firm Size - Using the number of employees within the firm

\section{RESULTS}

We employ General Estimation Equation (GEE) regression techniques using STATA 11. GEE recognizes that variables may be endogenously clustered such that observations within companies and across years in our panel data set are likely autocorrelated and this must be accounted for. Our statistical conclusion validity meets three basic conditions necessary for causal inference. We tested our models independently; however, VIFs (variance inflation factors) for each predictor variable were below 1.48 and the average VIF for all the covariates was below 1.29. This suggests multicollinearty is not an issue in this research study, as the cutoff point is 10.0 for any individual predictor variable VIF and 3.0 for the average VIF for all the covariates (Schroeder et al., 1990). A correlation matrix is also provided below including all variables (see Table 1). 
Table 1 Correlation Matrix with Significance Listed Beneath Standardized Coefficients.

\begin{tabular}{|c|c|c|c|c|c|c|c|c|c|}
\hline \multicolumn{10}{|c|}{ Cerrelatlens } \\
\hline & & $\begin{array}{l}\text { 11 der } \\
\text { unferes }\end{array}$ & 11. roum an & $\begin{array}{l}\text { ti endron } \\
\text { dledesure } \\
\text { sears }\end{array}$ & 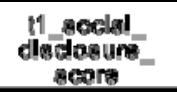 & $\begin{array}{l}\text { Indusiry } \\
\text { gery manu }\end{array}$ & $\begin{array}{c}\text { anomla- } \\
\text { atsels }\end{array}$ & $\begin{array}{l}\text { t1 lag } \\
\text { amplersens }\end{array}$ & $\begin{array}{c}\text { exuntrgergln } \\
\text { and }\end{array}$ \\
\hline I_dor_unflens: & $\begin{array}{l}\text { Pasrean Corralelon } \\
\text { ilg. (2-4ailed) } \\
\text { N }\end{array}$ & $\begin{array}{r}1 \\
1413 \\
\end{array}$ & & & & & & & \\
\hline 11_rehum_on_asaet & $\begin{array}{l}\text { Pearaon Correlatan } \\
\text { Sig. (2-biled) } \\
\text { N }\end{array}$ & $\begin{array}{r}-.037 \\
.184 \\
1413\end{array}$ & $\begin{array}{r}1 \\
1413\end{array}$ & & & & & & \\
\hline $\begin{array}{l}\text { H_emiren_dlaclosurs_- } \\
\text { gron }\end{array}$ & $\begin{array}{l}\text { Pasrean Conslation } \\
\text { sig. (2-halled) } \\
\text { i }\end{array}$ & $\begin{array}{r}-299 " \\
1060 \\
1227\end{array}$ & $\begin{array}{r}807 \\
8163 \\
1227\end{array}$ & $\begin{array}{r}1 \\
1227 \\
\end{array}$ & & & & & \\
\hline $\begin{array}{l}\text { I1_gedial_discdabure_ } \\
\text { gacere }\end{array}$ & $\begin{array}{l}\text { Paarsen Correlaion } \\
\text { Sh. (2-kiled) } \\
\text { N }\end{array}$ & $\begin{array}{r}-.142^{\text {n }} \\
.000 \\
1264\end{array}$ & $\begin{array}{r}-.071^{\prime} \\
012 \\
1264\end{array}$ & $\begin{array}{r}09^{\prime \prime} \\
000 \\
1227\end{array}$ & $\begin{array}{r}1 \\
1264\end{array}$ & & & & \\
\hline inclusty_gers_manu & $\begin{array}{l}\text { Pearsen Consiaion } \\
\text { Slg. (2-talled) } \\
\text { N }\end{array}$ & $\begin{array}{r}.238^{\circ} \\
.609 \\
1413\end{array}$ & $\begin{array}{r}\text {-388" } \\
609 \\
1413 \\
\end{array}$ & $\begin{array}{r}-168^{3} \\
\text { 008 } \\
1227 \\
\end{array}$ & $\begin{array}{r}., 082 \\
, 267 \\
1254 \\
\end{array}$ & $\begin{array}{r}1 \\
1413 \\
\end{array}$ & & & \\
\hline acenamis_erkisis & $\begin{array}{l}\text { Paamon Cerrelaian } \\
\text { Gig. (2-hiled) } \\
\text { N }\end{array}$ & $\begin{array}{r}.061 \\
.021 \\
1413\end{array}$ & $\begin{array}{r}.114^{m} \\
.000 \\
1413\end{array}$ & $\begin{array}{r}.139 \\
.000 \\
1227\end{array}$ & $\begin{array}{r}.100 \\
.000 \\
1264\end{array}$ & $\begin{array}{r}.016 \\
.538 \\
1413 \\
\end{array}$ & $\begin{array}{r}1 \\
1413 \\
\end{array}$ & & \\
\hline H_log_enployes & $\begin{array}{l}\text { Pesrson Conelaion } \\
\text { \&lg. (2-tailad) } \\
\text { N }\end{array}$ & $\begin{array}{r}-228^{\prime \prime} \\
.608 \\
1413\end{array}$ & $\begin{array}{r}-., 852 \\
.238 \\
1413\end{array}$ & $\begin{array}{r}0.044^{\circ} \\
.028 \\
1227\end{array}$ & $\begin{array}{r}.024 \\
.393 \\
1254\end{array}$ & $\begin{array}{r}.028 \\
206 \\
1413 \\
\end{array}$ & $\begin{array}{r}., 020 \\
.484 \\
1413\end{array}$ & $\begin{array}{r}1 \\
1413\end{array}$ & \\
\hline counitgarigin_waed & $\begin{array}{l}\text { Puarson Correlaian } \\
\text { Elg. (2-biled) } \\
\text { N }\end{array}$ & $\begin{array}{r}-3955^{n} \\
.000 \\
1413\end{array}$ & $\begin{array}{r}-.028 \\
.284 \\
1413\end{array}$ & $\begin{array}{c}200^{11} \\
000 \\
1227\end{array}$ & $\begin{array}{r}011 \\
\text { 328 } \\
1254\end{array}$ & $\begin{array}{r}530 \\
257 \\
1413\end{array}$ & $\begin{array}{r}-139^{\prime \prime} \\
0200 \\
1413\end{array}$ & $\begin{array}{r}.1884 \\
.0 \times 0 \\
1413\end{array}$ & $\begin{array}{r}1 \\
1513\end{array}$ \\
\hline
\end{tabular}

". Correlation is oigniflent at the 0.01 lowe (2-ailed).

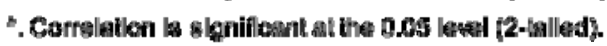


Hypothesis 1a argued that a positive and significant relationship existed between regionalization and a firm's economic performance. Results indicate that while controlling for firm size, industry, and the period fixed effect of economic crisis that a negative relationship exists between these variables (see Table 2). This relationship is not in the predicted direction nor is it significant and thus support is not found for hypothesis 1a.

Table 2 General Estimation Equation Clustering Company and Year Showing with Regression on Economic Performance.

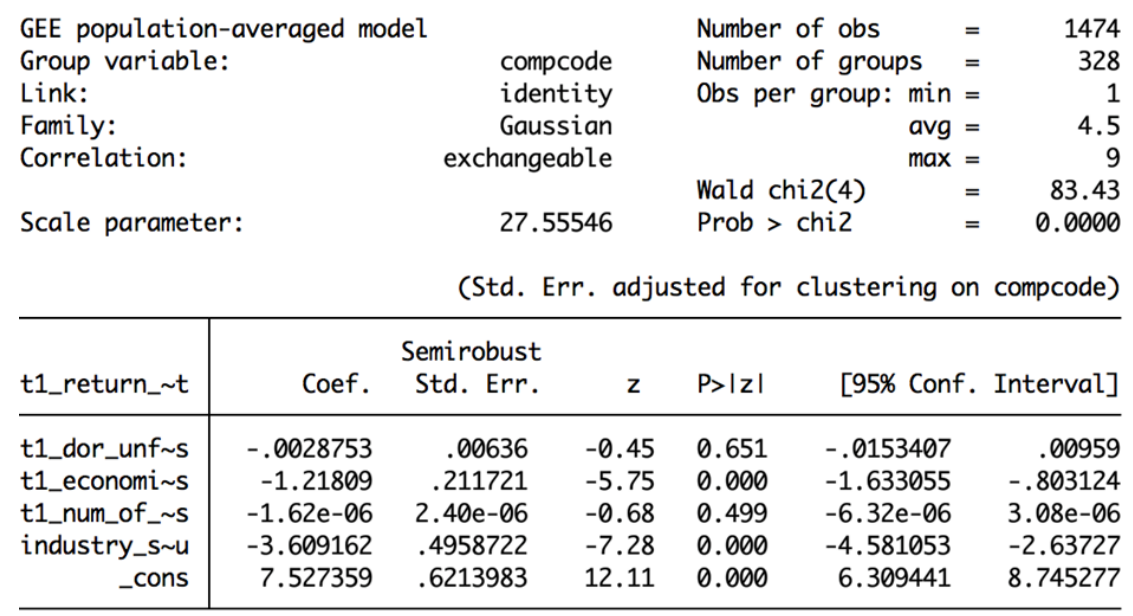

Hypothesis $1 \mathrm{~b}$ posited that the relationship between regionalization and economic performance would be negatively moderated by industry globalization. Results indicate that while controlling for firm size, industry, and the period fixed effect of economic crisis that the relationship between regionalization and economic performance negatively moderated by industry globalization as predicted (see Table 3). Results are not significant however thus hypothesis $1 \mathrm{~b}$ is not supported. 
Table 3 General Estimation Equation Clustering Company and Year Showing with Regression on Economic Performance and Industry Globalization Moderation.

\begin{tabular}{|c|c|c|c|c|c|c|}
\hline \multicolumn{4}{|c|}{ GEE population-averaged model } & \multicolumn{3}{|c|}{ Number of obs $\quad=\quad 1474$} \\
\hline \multicolumn{4}{|c|}{ Group variable: } & \multicolumn{3}{|c|}{ Number of groups $=328$} \\
\hline \multicolumn{2}{|c|}{ Link: } & \multicolumn{2}{|c|}{ identity } & \multicolumn{3}{|c|}{ Obs per group: $\min =$} \\
\hline \multicolumn{2}{|l|}{ Family: } & \multicolumn{2}{|c|}{ Gaussian } & \multicolumn{2}{|c|}{ avg $=$} & 4.5 \\
\hline \multirow{2}{*}{\multicolumn{2}{|c|}{ Correlation: }} & \multicolumn{2}{|c|}{ exchangeable } & & $\max =$ & \\
\hline & & \multirow{2}{*}{\multicolumn{2}{|c|}{27.5964}} & \multicolumn{2}{|c|}{ Wald $\operatorname{chi2}(6)=$} & 87.09 \\
\hline \multicolumn{2}{|c|}{ Scale parameter: } & & & \multicolumn{2}{|c|}{ Prob $>$ chi2 } & 0.0000 \\
\hline \multicolumn{7}{|c|}{ (Std. Err. adjusted for clustering on compcode) } \\
\hline & & Semi robust & & & & \\
\hline t1_return_ t & Coef. & Std Frr & z & $P>|z|$ & [95\% Conf. & Interval] \\
\hline nc_t1_ind & & 1.82714 & 1. & & -1.044598 & 6.117661 \\
\hline mc_t1_dor_ s & -.0011794 & .0065419 & -0.18 & 0.857 & -.0140013 & .0116425 \\
\hline nflor_inglo & -.0267289 & .0545929 & -0.49 & 0.624 & -.133729 & .0802712 \\
\hline t1_economi s & -1.173927 & .2144342 & -5.47 & 0.000 & -1.59421 & -.753643 \\
\hline t1_num_of_ s & $-1.40 \mathrm{e}-06$ & $2.39 e-06$ & -0.59 & 0.559 & $-6.08 e-06$ & $3.28 \mathrm{e}-0$ \\
\hline industry_s u & -3.321381 & .5483685 & -6.06 & 0.000 & -4.396164 & -2.246599 \\
\hline _cons & 7.148574 & .5062374 & 14.12 & 0.000 & 6.156367 & 8.140781 \\
\hline
\end{tabular}

Hypothesis $2 \mathrm{a}$ argued that a negative and significant relationship existed between regionalization and a firm's economic performance. Results indicate that while controlling for firm size, industry, and the period fixed effect of economic crisis that a significant $(p<.001)$ negative relationship exists between these variables (see Table 4$)$. This relationship is in the predicted direction thus supporting hypothesis $2 \mathrm{a}$.

Table 4 General Estimation Equation clustering company and year showing with regression on Environmental Performance.

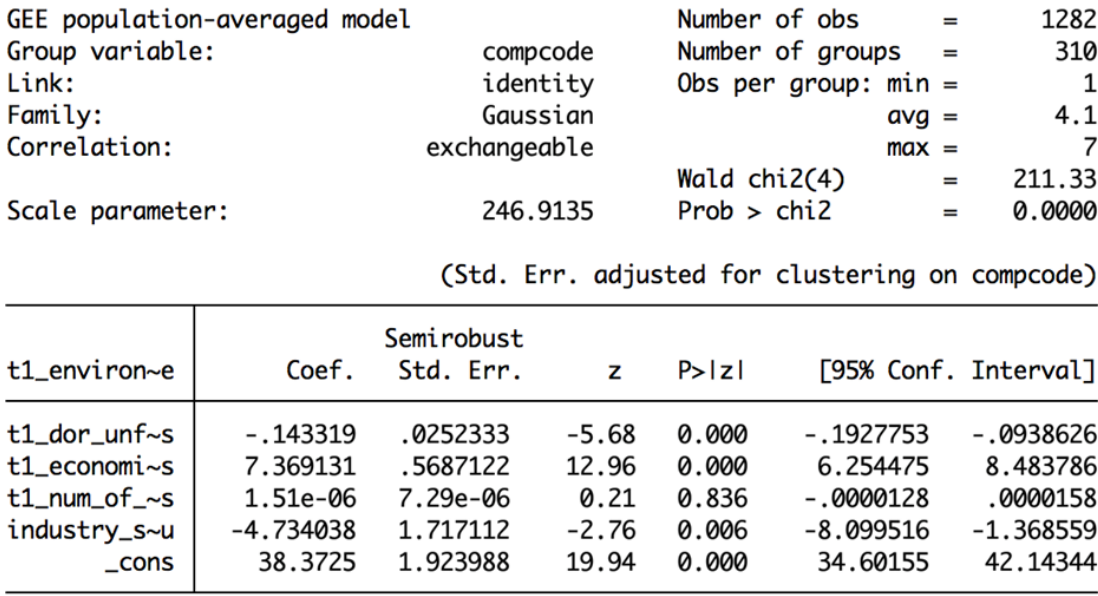


Hypothesis $2 \mathrm{~b}$ posited that the relationship between regionalization and economic performance would be negatively moderated by industry globalization. Results indicate that while controlling for firm size, industry, and the period fixed effect of economic crisis that the relationship between regionalization and economic performance negatively moderated by industry globalization as predicted (see Table 5). Results however are not significant however thus hypothesis $2 b$ is not supported.

Table 5 General Estimation Equation Clustering Company and Year Showing with Regression on Environmental Performance and Industry Globalization Moderation.

\begin{tabular}{|c|c|c|c|c|c|c|}
\hline \multirow{2}{*}{\multicolumn{4}{|c|}{ GEE population-averaged model }} & \multirow{2}{*}{\multicolumn{3}{|c|}{ Number of obs }} \\
\hline & & & & & & \\
\hline \multicolumn{4}{|c|}{ Group variable: } & Number & f groups & 310 \\
\hline \multicolumn{2}{|c|}{ Link: } & \multicolumn{2}{|c|}{ identity } & \multicolumn{3}{|c|}{ Obs per group: $\min =$} \\
\hline \multicolumn{2}{|l|}{ Family: } & \multicolumn{2}{|c|}{ Gaussian } & & avg $=$ & 4.1 \\
\hline \multirow{2}{*}{\multicolumn{2}{|c|}{ Correlation: }} & \multicolumn{2}{|c|}{ exchangeable } & & $\max =$ & 7 \\
\hline & & & & Wald $\mathrm{cr}$ & $2(6)$ & 212.37 \\
\hline \multicolumn{2}{|c|}{ Scale parameter: } & 247 & 539 & Prob > & hi2 & 0.0000 \\
\hline \multicolumn{7}{|c|}{ (Std. Err. adjusted for clustering on compcode) } \\
\hline t1_environ e & Coef. & $\begin{array}{c}\text { Semirobust } \\
\text { Std. Err. }\end{array}$ & $z$ & $P>|z|$ & [95\% Conf. & Interval] \\
\hline mc_t1_indu s & -6.782376 & 5.493387 & -1.23 & 0.217 & -17.54922 & 3.984464 \\
\hline mc_t1_dor_ s & -.1482193 & .0256724 & -5.77 & 0.000 & -.1985363 & -.0979023 \\
\hline nflor_inglo & -.1339566 & .1663599 & -0.81 & 0.421 & -.4600161 & .1921029 \\
\hline t1_economi s & 7.307723 & .572313 & 12.77 & 0.000 & 6.18601 & 8.429436 \\
\hline t1_num_of_ s & $4.62 \mathrm{e}-07$ & $7.31 \mathrm{e}-06$ & 0.06 & 0.950 & -.0000139 & .0000148 \\
\hline industry_s u & -5.175197 & 1.878071 & -2.76 & 0.006 & -8.856149 & -1.494246 \\
\hline _cons & 29.42314 & 1.488277 & 19.77 & 0.000 & 26.50618 & 32.34011 \\
\hline
\end{tabular}

Hypothesis $3 \mathrm{a}$ argued that a negative and significant relationship existed between regionalization and a firm's social performance. Results indicate that while controlling for firm size, industry, and the period fixed effect of economic crisis that a significant $(p<.05)$ negative relationship exists between these variables (see Table 6). This relationship is in the predicted direction thus supporting hypothesis 3 a. 
Table 6 General Estimation Equation Clustering Company and Year Showing with Regression on Social Performance.

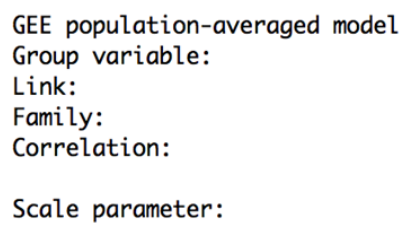

$\begin{array}{rlr}\text { Number of obs } & =1310 \\ \text { Number of groups } & = & 314 \\ \text { Obs per group: min } & = \\ \text { avg } & = & 1 \\ \max & = & 4.2 \\ \text { Wald chi2(4) } & = & 159.78 \\ \text { Prob }>\text { chi2 } & = & 0.0000\end{array}$

(Std. Err. adjusted for clustering on compcode)

\begin{tabular}{r|rrrrrr}
\hline & \multicolumn{5}{|c}{ Semirobust } \\
t1_social_ e & Coef. & Std. Err. & z & P $>|z|$ & [95\% Conf. Interval] \\
\hline t1_dor_unf s & -.0653333 & .0298724 & -2.19 & 0.029 & -.1238822 & -.0067844 \\
t1_economi s & 6.927446 & .5642868 & 12.28 & 0.000 & 5.821464 & 8.033427 \\
t1_num_of_ s & $-4.18 \mathrm{e}-06$ & $8.21 \mathrm{e}-06$ & -0.51 & 0.611 & -.0000203 & .0000119 \\
industry_s u & -1.041729 & 2.053626 & -0.51 & 0.612 & -5.066762 & 2.983305 \\
_cons & 38.82448 & 2.232643 & 17.39 & 0.000 & 34.44858 & 43.20038 \\
\hline
\end{tabular}

Hypothesis $3 \mathrm{~b}$ posited that the relationship between regionalization and social performance would be negatively moderated by industry globalization. Results indicate that while controlling for firm size, industry, and the period fixed effect of economic crisis that the relationship between regionalization and social performance positively moderated by industry globalization (see Table 7). Results are not significant however thus hypothesis $3 b$ is not supported.

Table 7 General Estimation Equation Clustering Company and Year Showing with Regression on Social Performance and Industry Globalization Moderation.

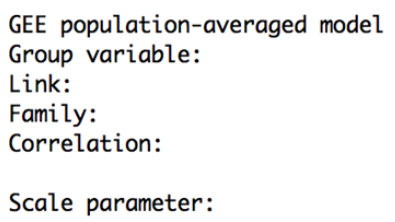

\begin{tabular}{r|rrrrrr}
\hline & \multicolumn{5}{|c}{ Semirobust } \\
t1_social_ e & Coef. & Std. Err. & $z$ & P $>|z|$ & [95\% Conf. Interval] \\
\hline mc_t1_indu s & -7.285671 & 6.286338 & -1.16 & 0.246 & -19.60667 & 5.035325 \\
mc_t1_dor_ s & -.0703038 & .0304861 & -2.31 & 0.021 & -.1300554 & -.0105521 \\
〜nflor_inglo & .1768329 & .1896591 & 0.93 & 0.351 & -.194892 & .5485579 \\
t1_economi s & 6.797769 & .5737521 & 11.85 & 0.000 & 5.673236 & 7.922303 \\
t1_num_of_ s & $-4.98 \mathrm{e}-06$ & $8.22 \mathrm{e}-06$ & -0.61 & 0.545 & -.0000211 & .0000111 \\
industry_s u & -1.994108 & 2.201175 & -0.91 & 0.365 & -6.308332 & 2.320116 \\
_cons & 35.45999 & 1.677805 & 21.13 & 0.000 & 32.17155 & 38.74842 \\
\hline
\end{tabular}

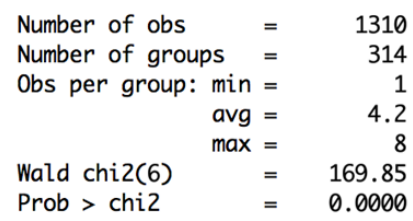

(Std. Err. adjusted for clustering on compcode) 


\section{DISCUSSION}

Robustness checks were performed using alternative measures of regionalization including classifications of three regions (Rugman), four regions (Hitt), and six regions (Dunning). These classifications were based on various overlapping dimensions of geography, culture, and socioeconomic development. Results were fairly consistent across these classifications and in addition entropy measures following the approach of Qian and colleagues (2008) were also consistent.

Additional variables were introduced as controls such as the historical market capitalization as an indicator of size, the industry concentration levels to address need for industry efficiency fit. These variables were mainly non-significant or were not as significant and yet highly related to control variables that were included (e.g., industry classification service or manufacturing was the most significant industry control so the

others were omitted). Interestingly, firm size as measured by number of employees did not prove to be a significant predictor of firm performance in any model. Service firms are shown to have performance on average than manufacturing which could be a result of the direct tie to the firm and personal nature of services. Using a period fixed effect to represent the economic crisis; it appeared firms had higher performance as a result of the economic crisis. While this result seems counterintuitive it may represent a direct effort by organizations to restore confidence in them and an attempt to create goodwill in order to compete in a tougher economy.

\section{Limitations \& Assumptions -}

The variable selection for performance allowed more flexibility on economic performance signals where return on equity and return on sales, inter alia, were also 
available and logical choices showing similar results. Environmental and social signal variables were limited and thus subject to criticism of convenience sampling. These variables did include several indicators commonly associated with the Global Reporting Initiative (GRI) and offered a comprehensive look at environmental and social performance which was adjusted by industry. In other words, while other options were available these measurements represented the most congruent measurements in accordance with our arguments, therefore providing the greatest content validity. The findings however are limited by reporting standards and therefore findings are subject to the limitations of our data.

\section{CONCLUSION}

This study brings a more fine-grained approach toward future studies of regional diversification and performance by examining alternative performance measures and industry interaction effects. Furthermore, it highlights strategic challenges managers face in light of industry reliance on global or regional efficiencies in order to create and exploit their firm's value proposition internationally. Analysis reveals that future broadbase studies linking regionalization and performance should examine likely sources of variation, which have been previously noted in MP research also illustrating a need for methodological rigor. Lastly, the resulting study may impact managers' decisions surrounding scope of business operations (i.e. corporate diversification strategies) related to industry-specific efficiency needs driving global or regional configuration strategies. 


\section{WHAT IS THE MEDIATING EFFECT OF ‘TRIPLE BOTTOM-LINE' MEASURES OF FIRM PERFORMANCE ON FIRM REPUTATION?}

\section{INTRODUCTION}

Having a good reputation is important as it has been linked to many positive outcomes (Fombrun \& Shanley, 1990) such as attracting investors (Milgrom \& Roberts, 1986), attracting consumers (Parker \& Lessig, 1981), attracting higher quality job seekers (Highhouse et al., 1996), as well as sustained financial performance (Roberts \& Dowling, 2002). Consequently, reputation building is seen as an increasingly important part of competitive strategy building (Dowling, 1986; Williams et al., 2005; Barney, 1991). Yet although reputation is increasingly acknowledged as a valuable strategic resource, it is very rare and the antecedents to its formation are sometimes ambiguous. Furthermore, corporate reputation is considered a socially constructed concept determined by the firm's ability to behave in a manner consistent with the cultural ideals of its audience (Love \& Kraatz, 2009; Rao, 1994). Consequently, understanding the value of corporate reputation will be greatly enriched by addressing two questions; 1) what signals (e.g., economic, environmental, social disclosures) impact its formation, and 2) what is the impact of operating across increasingly distant regions on corporate reputation vis-à-vis such signals?

Corporate reputation may be conceived as 'the overall knowledge and esteem of the corporation held by the general public' (Fombrun, 1996; Newburry, 2010); however, the extent of knowledge and esteem held by the public may vary considerably among different stakeholder groups (Fombrun \& Shanley, 1990). The ability of a firm to possess 
a favorable reputation is largely determined by its audience which compares its behavioral conformity toward a socially constructed ideal, which may vary widely in accordance with cultural differences (Love \& Kraatz, 2009; Rao, 1994). As such the public will reward a firm with a good reputation if it 'exemplifies cultural stipulations and ideals' and penalize those that do not do the same (Love \& Kraatz, 2009:316), making this a particularly difficult endeavor to manage across differing regions. Societal pressures challenge firms to maintain legitimacy in their home markets, leading to what some refer to as industrial 'isomorphism' (DiMaggio \& Powell, 1983), and further inhibit a firm's ability to transfer successful practices across complex international and cultural boundaries (Kostova \& Zaheer, 1999) as a consequence.

Firms therefore have difficulty attempting 'globalize' their operations, which are effectively optimized for regional-specific conditions, and consequently must internationally diversify in more regional than global patterns (Collinson \& Rugman, 2008; Ohmae, 1985). Ohame (1985) did however suggest that some truly global firms, or "Triad Powers" as he referred to them, could successfully deploy their advantages across the major economic regions of the world. These global powers undoubtedly must possess superior competitive advantages vis-à-vis their more regional competitors which both allows and warrants greater international dispersion of their assets. These firms which diversify beyond their home regions face greater pressure to maintain organization legitimacy in foreign markets in which they operate (Kostova \& Zaheer, 1999) and must therefore adapt to the expectations of their host regions. While firms adopt new practices and policies in accordance with the formal and informal rules of host societies, they must also attempt to maintain legitimacy in their home region. 
Accordingly, "Triple Bottom Line" performance measures (Elkington, 2004), which can be thought of as a reflection of a firm's ability to meet economic, social, and environmental norms, relevant to a broad range of constituents, may be mediating antecedents of reputation. While firms that internationalize only regionally may have easier time meeting these norms, firms that expand beyond their home region will likely develop processes for meeting the norms of foreign cultural and administrative ideals and therefore develop more creating more signals which may be converted into reputation (see Figure 5 for a Conceptual Model). However the effect of regionalization on these signals and in return reputation may not always be complementary. In the remainder of the paper we first will briefly review the literature surrounding reputation and signaling. Second, we will posit theory and hypotheses involving the relationship between regionalization and firm reputation, as well as, the mediating antecedents of economic, environmental, and social signals. Third, we discuss our methodological approach to addressing our hypotheses including sample and variables. Fourth, we discuss our results and applicable statistical procedures. We then offer a discussion on interesting results, robustness checks, as well as assumptions and directions for future research before providing a conclusion. 
Figure 5 Conceptual Model of Mediation Effects 'Triple Bottom-Line' Measures on Relationship between Regionalization and Firm Reputation

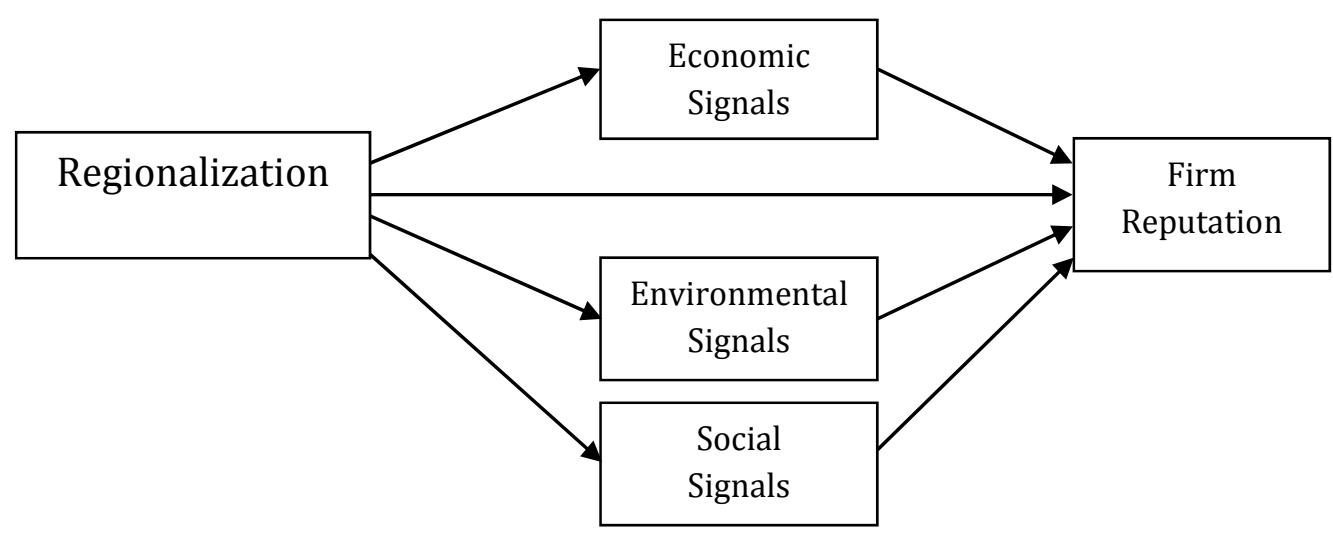

\section{LITERATURE REVIEW}

\section{Reputation -}

Firms receive beneficial outcomes from having a reputation for "quality", "trustworthiness", or "toughness" in business dealings, inter alia, and such distinctions are cultivated over long periods of time and are not simply acquired for use in the "strategic factor market" (Dierickx \& Cool, 1999). Reputation can therefore be considered a form of collateral used in lieu of other transaction costs, or premiums, and which must be established by initial expenditures and the forfeiture of short-run gains from opportunistic behavior (Klein, Crawford, and Alchian 1978). Corporate reputation is also an outcome determined by firm behavior in the past and "the premium stream is then merely a normal rate of return on the "reputation," or "brand-name" capital created by the firm by these initial expenditures (Klein et al., 1978: 306)". A firm's reputation could therefore be conceived as a stockpile of excess returns in performance in the form of intangible assets which is accumulated over time. Thus, the formation of a favorable 
reputation is, at least partially, determined by previously meeting performance expectations of multiple stakeholders, which in turn indicates a firm's ability to meet their current and future expectations (Fombrun \& Shanley, 1990; Wilson, 1985).

Deviation from formal and informal rules of a society can have many negative consequences for an organization such as loss of legitimacy (Kostova \& Zaheer, 1999; DiMaggio \& Powell, 1983). Yet reputation, which is thought to derive from similar antecedents to those that form legitimacy (Deephouse \& Carter, 2005), also involves comparing an organization's performance relative to its counterparts (Shenkar \& Yuchtman-Yaar, 1997) rather than just symbolic conformity to societal norms (Love \& Kraatz, 2009). Moreover, reputation is said to be assessed on dimensions beyond those that help determine legitimacy (Ruef \& Scott, 1998; Deephouse \& Carter, 2005) and is therefore subject to importance of each dimension given by the set of relevant firm stakeholders (Boyne, 2003; Fombrun \& Shanley, 1990; Freeman; 1984).

\section{Signaling Theory-}

Signaling theory largely evolves from the belief that decisions are made under uncertainty (Spence, 1973). Spence also argues that the development of signals, meant to reduce informational asymmetries, is contingent upon the expected return on investment in signal generation. The expected return is determined by the quality of the signal as determined by the receiver and the likelihood the receiver will in fact see the signal. In sum, if the benefits of signal generation and management are lower than the costs to create and maintain, it is a wise investment for the firm.

Signaling theory originally examined signals in the job market; however, later scholars explored the use of signals with organizations (Ross, 1977) and products 
(Kirmani and Rao, 2000). Scholars have naturally linked signals from firms (e.g., marketing intensity, media exposure, accounting profitability, market risk and performance, etc.) to assessments of firm reputation (Fombrun and Shanley, 1990). The informational asymmetries which exist between firms and the public often arise because of the nature of information, public or private, which is also related to signaling environment (Connelly et al., 2011). Some firm signals are communicated in person, others online and through the media, some signals are meant for other businesses, potential employees, investors, or customers. Thus, the signaling environment (i.e., where and what signals are sent and received) will play a role in determining the signaling costs and the long-term benefits and is an important area of future research (Conelly et al., 2011). Controlling these signals in an age where information is readily mass communicated through the media (e.g., internet, television) and therefore the signal environment is clouded by competing signalers (i.e., other firms) is more difficult than ever (Connelly et al, 2011; Deephouse, 2000).

\section{THEORY \& HYPOTHESES}

Value, in products and services, is created through the sequential integration of many 'technologically-separable' tasks within the firm, throughout efficient external markets, or a combination of the two (Hennart, 2011). When market efficiencies are needed or value is significantly derived from transfer of knowledge or reputation for products and services, this becomes increasingly difficult outside the home-market (Hennart, 1982; 2011). Indeed, when transferring value-adding firm-specific advantages and organizational practices across borders MNCs often face challenges in maintaining organizational legitimacy (Kostova \& Zaheer, 1999) which generally requires an 
imperfect compromise between efficiency and conformity. While decision makers rarely fully anticipate the challenges they will face from operating abroad, internalization theory provides some insight into where firms locate and what mode of entry they choose (Buckley \& Casson, 1976; 1998). Ceteris paribus, firms will only locate in areas and choose modes of entry where they feel they can continue to exploit their value-adding proposition. Reputation is an important value-adding component of competitive strategy building (Barney, 1991; Roberts \& Dowling, 2002) heavily reliant on symbolic conformity and legitimacy (Love \& Kraatz, 2009; Shenkar \& Yuchtman-Yaar, 1997). Firms derive most of their beneficial outcomes from firm-specific advantages created in their home region, some of which are brand name and reputation-based, and these FSAs are not easily exploited outside the home region (Collinson \& Rugman, 2008; Ohmae, 1985; Rugman \& Verbeke, 2004). Thus, we propose the following:

H1. There is a positive relationship between regionalization and firm reputation.

Although scholars have argued that having a good reputation allows firms to charge premiums for their goods and services (Milgrom \& Roberts, 1986) and attracts better resources important for sustained financial performance (Roberts \& Dowling, 2002), it seems the reverse is also true (Roberts \& Dowling, 2002). Superior performance may also provide firms the opportunity to engage in socially responsible ways that lead to better reputation (McGuire, Sundgren, \& Schneeweis, 1988; Campbell, 2007). Indeed, more traditional performance measures seem to provide good indications of firm reputation. Better market performance and profitability, are argued to be 
positively related to firm reputation (Fombrun \& Shanley, 1990), and regionalization is shown to have be related to traditional performance measures. Thus, I propose the following:

H2. There is a positive relationship between regionalization and firm reputation that is mediated by economic performance signals.

From a resource-based perspective (RBV), Russo and Fouts (1997) argue that environmental performance and profitability are linked as higher environmental performance leads to the creation of intangible assets such as reputation (Hall, 1992). Indeed, in a "Natural-Resource-Based View of the Firm", Hart (1995) also argues that there is a great deal of unclaimed space for reputation for those firms that show product stewardship, pollution prevention, and sustainable development. However, King and Shaver (2001) show that production of waste increases as the complexity of managing multiple jurisdictions is increased. Product stewardship, that could be attributed to green supply chain management initiatives, also diminishes as collaboration between buyers and suppliers diminishes (Vachon \& Klassen, 2006), a likely outcome of communication complexity in international supply chain management (Prater, Biehl, \& Smith, 2001). As it appears regionalization increases the likelihood of developing sustainable practices, it must also enhance reputation. Thus I propose the following:

H3. There is positive relationship between regionalization and firm reputation that is mediated by environmental disclosure signals. 
Contributions to social welfare generate goodwill from employees, consumers, and other members of the public that can lead to a better reputation (Fombrun \& Shanley, 1990). This relationship is bound by the firm's ability to please multiple stakeholders within the task environment (Pfeffer \& Salancik, 1978). As well, the scarce resources of the firm that may be allocated to such social responsibility enhancement (Haugh \& Talwar, 2010) and the increased difficulty of maintaining legitimate practices in foreign locations (Kostova, 1999; Kostova \& Zaheer, 1999) make building and maintaining reputation more difficult as internationalization increases. Indeed, firms often regionalize due to the lack of transferability of firm-specific assets built upon conditions in the local environment (Collinson \& Rugman, 2008). As such, socially responsible practices that are likely country or region-specific are difficult to diffuse across international boundaries. Thus, I propose the following:

H4. There is positive relationship between regionalization and firm reputation that is mediated by social disclosure signals.

\section{METHODOLOGY}

$\underline{\text { Sample }}$

Our dependent variable, Corporate Reputation, was based on the Reputation Institute's annual study of the world's largest 600 firms (based on sales) from 2006-2011. Data for these companies was then merged from the Directory of Corporate Affiliates (DCA) and Bloomberg using period years 2004-2011 which allowed for lagging of the 
regionalization construct by T-2 years (i.e., company-year 2006 reputation may be predicted by company-year 2004 value of regionalization). Beginning with 3600 potential observations by company-year ( 6 years * 600 companies), the data set is reduced to 2971 observations through variation in the world's 600 largest companies during the period of 2006-2011(i.e., some firms join the list and others fall off) and availability of data at the subsidiary and other levels (a majority of missing sample data was from firms in emerging markets - e.g. China). An additional 23 independent and outlying observations were deleted when significant abnormal deviation from the variable range was detected. Such deletions included the 2008 AIG report of $-14 \%$ return on equity resulting from losses totaling nearly $\$ 62$ Billion, isolated incidences of severe negative return on assets (e.g. Delta Airlines), and in one case a negative value in goodwill reported by a company from Thailand. Due to the nature of our argument surrounding international operations, and the difficulties in managing across regions, several firms with a very low number of employees (less than 500) were also omitted. The final sample size by company-year without missing variables was 1465 . The roughly $51 \%$ reduction from company year observations is largely a result of availability of environmental and social variables. A larger sample was available for tests of mediation with respect to economic signals and is reported in the results.

\section{Dependent Variable}

Corporate Reputation - Our dependent variable includes reputation scores derived from the Reputation Institute's reputation survey which aims to measure multiple facets of corporate reputation. The reputational scores of each firm represent a respondent pool, 
from a well-established data collection agency, which operates in all of the study countries and reflects the reputation as evaluated by home country respondents. In order to be eligible for the study, possible respondents must meet the minimal requirement of being at least 'somewhat familiar' with the focal company of assessment and this is based on their ability to answer 3 out of 4 general questions regarding the company (Asher, 2004). This reputation 'pulse' score is derived from evaluations of the population beyond industry insiders which is often the source of such frequently employed proxy for reputation, Fortune's annual report on the World's Most Admired Companies.

The respondents included rated companies from their home country. The pulse score measure of reputation consists of four items (Newburry, 2010):

1. This is a company with a "good overall reputation"

2. This is "a company I have a good feeling about"

3. This is "a company that I trust"

4. This is "a company that I admire and respect"

\section{$\underline{\text { Independent Variables }}$}

Regionalization - Hennart (2011) identifies the use of inappropriate multinationality constructs, whereby the theory researchers build their hypotheses on is incongruent with the operationalization of multinationality, as a rampant methodological problem in MP research. Researchers have shown that how multinationality is measured in many cases using regions for diversification measurement, or how regions are defined; affects the findings on firm outcomes such as locational choice and performance (Flores \& Aguilera, 2007). Rugman and Oh (2010) employ the commonly used ratio technique 
examining regional sales to total sales RSTS, with their adapted "Triad" regional classification created by Ohmae (1985). Qian and colleagues (2010) apply similar alternative classification based upon economic development and follow entropy techniques similar to Hitt and collegues (1997). We employ a degree of regionalization measure calculated as the percentage of subsidiaries located in the MNCs' home region. We follow the Flores and Aguilera (2007) classification approach using the UN distinctions of 23 regions. This value ranged from 0 to 1 and was lagged T-2 years. This approach is most closely in line with our arguments surrounding disclosures which would be mainly attributable to operational activities rather than sales alone. The UN classification scheme involving 23 regions is also the most parsimonious and aptly recognizes regional idiosyncrasies better than other more broad classifications employed by Hitt and colleagues (1997) or Rugman and Oh (2010) with 4 and 3 regions respectively.

Mediating Variables -There are three mediating variables to be employed in separate models and simultaneously.

Economic Signals - There are several measures available as potential signals of economic performance. Return on sales is a widely used measure and helps avoid the potential bias in total assets between service and manufacturing firms; however, sales may vary significantly from year to year creating inconsistent results. Return on equity is an often employed measure yet does not adequately reflect the international nature and varying ownership structure found in our sample. Thus, we employ the firm's Return on Assets (ROA) given by Bloomberg and lagged T-1 years. Service firms may also possess 
significant and recordable amounts of assets suitable for comparison to manufacturing firms. In addition, assets are more stable than sales year on year and also reflect a more closely aligned operationalization of economic signaling given the use of foreign subsidiaries in our regionalization variable.

Environmental Signals - Environmental Disclosure scores, theoretical range of 0 to $100 \%$ where $100 \%$ indicates greatest disclosure, take from Bloomberg which also takes into account industry, and lagged T-1 years. This variable includes quantifiable indicators such as total carbon emissions, renewable energy credits as a percent of revenues, waste and water consumption per employee, and as well qualitative indicators such as third party environmental assessment, green building policies, and green supply chain management policies.

Social Signals - Social Disclosure scores which have a theoretical range of 0 to $100 \%$ where $100 \%$ indicates greatest disclosure, take from Bloomberg which also takes into account industry, and lagged T-1 years. This variable includes quantifiable indicators such as lost time for accidents and training per employee, and as well qualitative indicators like community spending as a percent of pre-tax profit (if greater than $1 \%$ then yes), and policies on health, fair remuneration, equal opportunity and human rights.

\section{Control Variables -}

Firm industry - Dichotomous for service firms and 0 for manufacturing following Rugman \& Oh, (2005) these are shown to be regional or global in their asset orientation.

Firm Risk - Raw equity scores from Bloomberg and lagged T-2 years, risk has be show to significantly impact firm reputation. 
Economic Crisis - Dichotomous 1 for years 2006-2007; 2010 and for years 20082009

Firm Size - Historic market capitalization lagged T-2 from Bloomberg, as visibility has been show to significantly impact reputation.

\section{RESULTS}

We employ structural equation modeling (SEM) regression techniques using AMOS software by IBM. SEM by default implies causality by the pathways modeling relationships between variables and theses pathways rest upon theoretical justification and statistical approach toward testing. Our statistical conclusion validity meets three basic conditions necessary for causal inference. First, all predictor variables are lagged at least T-1 years such that temporal precedence occurs in our pathways. Second, we statistically control for several likely contributors to variance in corporate reputation in an attempt to rule out alternative explanations. Third, as will be shown there are appropriate significant correlations between our predictor and criterion variables indicating that a relationship does exist beyond what can be explained by chance. We tested several models independently and the also included a full model wherein all variables were used. VIFs (variance inflation factors) for each predictor variable were below 1.48 and the average VIF for all the covariates was below 1.29; suggesting multicollinearty is not an issue in this research study, as the cutoff point is 10.0 for any individual predictor variable VIF and 3.0 for the average VIF for all the covariates (Schroeder et al., 1990). Descriptive statistics are provided including mean, standard deviation and sample size (see Table 8 below) and a correlation matrix is also provided (see Table 9 below) 
Table 8 Showing Variable List of Means, Standard Deviations and Observations

\begin{tabular}{|l|r|r|l|}
\hline & \multicolumn{1}{|c|}{ Mean } & Std. Deviation & \multicolumn{1}{l|}{$\mathrm{N}$} \\
\hline Pulse_r_mean & 65.8635 & 10.00959 & 1465 \\
T1_return_on_asset & 4.982682 & 5.8494869 & 1465 \\
T1_environ_disclosure_ & 32.987964 & 16.7340238 & 1465 \\
score & & & \\
T1_social_disclosure_ & 38.714819 & 17.9599762 & 1465 \\
score & & 31.4646207 & 1465 \\
T1_dor_unflores & 56.002712 & .500 & 1465 \\
industry_serv_manu & .49 & .497 & 1465 \\
T1_economic_crisis & .44 & $5.8370137 \mathrm{E} 4$ & 1465 \\
T1_historical_market_ & $5.099810 \mathrm{E} 4$ & 5.05 & \\
cap & & .4326387 & 1465 \\
T1_eqy_raw_beta & 1.063366 &
\end{tabular}

There is considerable variance in range, as indicated by the standard deviations, excluding the dichotomous variables which also indicated a roughly balanced number of observations between service and manufacturing firms and the periods within and outside the economic crisis. 
Table 9 Matrix Showing Pairwise Variable Correlations

Correlations $^{\mathrm{a}}$

\begin{tabular}{|c|c|c|c|c|c|c|c|c|c|c|}
\hline & & $\begin{array}{l}\text { Pulse r } \\
\text { mean }\end{array}$ & $\begin{array}{l}\text { T1_return } \\
\text { on_asset }\end{array}$ & $\begin{array}{l}\text { T1_environ_ } \\
\text { disclosure- } \\
\text { score }\end{array}$ & $\begin{array}{l}\text { T1_social__ } \\
\text { disclosure_ } \\
\text { score }\end{array}$ & $\begin{array}{l}\text { T1 dor } \\
\text { unflores }\end{array}$ & $\begin{array}{l}\text { industry } \\
\text { serv_manu }\end{array}$ & $\begin{array}{l}\mathrm{T}^{1} \\
\text { economic } \\
\text { crisis }\end{array}$ & $\begin{array}{l}\text { T1_historical__ } \\
\text { market_cap }\end{array}$ & $\begin{array}{c}\text { T1_eqy_raw_ } \\
\text { beta }\end{array}$ \\
\hline Pulse_r_mean & $\begin{array}{l}\text { Pearson Correlation } \\
\text { Sig. (2-tailed) }\end{array}$ & 1 & & & & & & & & \\
\hline T1_return_on_asset & $\begin{array}{l}\text { Pearson Correlation } \\
\text { Sig. (2-tailed) }\end{array}$ & $\begin{array}{l}.211^{* *} \\
.000\end{array}$ & 1 & & & & & & & \\
\hline $\begin{array}{l}\text { T1_environ_disclosure_ } \\
\text { score }\end{array}$ & $\begin{array}{l}\text { Pearson Correlation } \\
\text { Sig. (2-tailed) }\end{array}$ & $\begin{array}{r}-.112^{* *} \\
.000\end{array}$ & $\begin{array}{l}.038 \\
.141\end{array}$ & 1 & & & & & & \\
\hline $\begin{array}{l}\text { T1_social_disclosure_ } \\
\text { score }\end{array}$ & $\begin{array}{l}\text { Pearson Correlation } \\
\text { Sig. (2-tailed) }\end{array}$ & $\begin{array}{r}-.119^{* *} \\
.000\end{array}$ & $\begin{array}{r}-.025 \\
.332\end{array}$ & $\begin{array}{l}.610^{* *} \\
.000\end{array}$ & 1 & & & & & \\
\hline T1_dor_unflores & $\begin{array}{l}\text { Pearson Correlation } \\
\text { Sig. (2-tailed) }\end{array}$ & $\begin{array}{l}.117^{* *} \\
.000\end{array}$ & $\begin{array}{r}-.078^{* *} \\
.003\end{array}$ & $\begin{array}{r}-.320^{* *} \\
.000\end{array}$ & $\begin{array}{r}-.163^{* *} \\
.000\end{array}$ & 1 & & & & \\
\hline industry_serv_manu & $\begin{array}{l}\text { Pearson Correlation } \\
\text { Sig. (2-tailed) }\end{array}$ & $\begin{array}{r}-.313^{* *} \\
.000\end{array}$ & $\begin{array}{r}-.322^{* *} \\
.000\end{array}$ & $\begin{array}{r}-.209^{* *} \\
.000\end{array}$ & $\begin{array}{r}-.070^{* *} \\
.007\end{array}$ & $\begin{array}{l}.259^{* *} \\
.000\end{array}$ & 1 & & & \\
\hline T1_economic_crisis & $\begin{array}{l}\text { Pearson Correlation } \\
\text { Sig. (2-tailed) }\end{array}$ & $\begin{array}{l}.161^{* *} \\
.000\end{array}$ & $\begin{array}{r}-.097^{* *} \\
.000\end{array}$ & $\begin{array}{l}.168^{* *} \\
.000\end{array}$ & $\begin{array}{l}.141^{* *} \\
.000\end{array}$ & $\begin{array}{l}.020 \\
.445\end{array}$ & $\begin{array}{r}-.014 \\
.603\end{array}$ & 1 & & \\
\hline $\begin{array}{l}\text { T1_historical_market_ } \\
\text { cap }\end{array}$ & $\begin{array}{l}\text { Pearson Correlation } \\
\text { Sig. (2-tailed) }\end{array}$ & $\begin{array}{r}-.056^{*} \\
.032\end{array}$ & $\begin{array}{l}.267^{* *} \\
.000\end{array}$ & $\begin{array}{l}.115^{* *} \\
.000\end{array}$ & $\begin{array}{l}.051 \\
.051\end{array}$ & $\begin{array}{r}-.153^{* *} \\
.000\end{array}$ & $\begin{array}{r}-.052^{*} \\
.045\end{array}$ & $\begin{array}{r}-.156^{* *} \\
.000\end{array}$ & 1 & \\
\hline T1_eqy_raw_beta & $\begin{array}{l}\text { Pearson Correlation } \\
\text { Sig. (2-tailed) }\end{array}$ & $\begin{array}{r}-.189^{* *} \\
.000\end{array}$ & $\begin{array}{r}-.312^{* *} \\
.000\end{array}$ & $\begin{array}{l}.025 \\
.334\end{array}$ & $\begin{array}{r}-.020 \\
.444\end{array}$ & $\begin{array}{r}-.191^{* *} \\
.000\end{array}$ & $\begin{array}{r}-.008 \\
.754\end{array}$ & $\begin{array}{l}.010 \\
.694\end{array}$ & $\begin{array}{r}-.056^{*} \\
.033\end{array}$ & 1 \\
\hline
\end{tabular}

**. Correlation is significant at the 0.01 level (2-tailed).

*. Correlation is significant at the 0.05 level (2-tailed).

a. Listwise $\mathrm{N}=1465$ 
Statistical Approach - Following the Baron \& Kenny (1986) argument, in order to test for mediation in hypotheses 2-4, we must first establish a relationships between regionalization and firm reputation, as argued in hypothesis 1 . We must then also establish significant relationships between each mediating variable (economic signals, environmental signals, and social signals) and firm reputation. Evidence of which is confirmed for all relationships $(\mathrm{p}<.001)$ in base models (see Table 10 for economic base model) alongside a significant relationship between regionalization and firm reputation.

Table 10 Base Model for Economic Signal Performance with Unstandardized Regression Weights and Significance Levels.

Regression Weights: (Group number 1 - Default model)

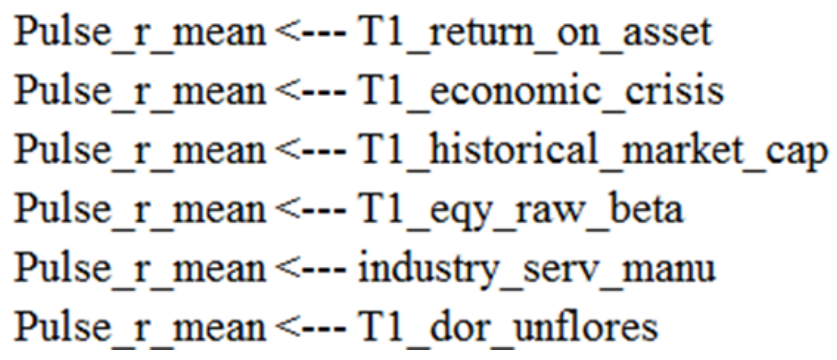

$\begin{array}{rc}\text { Estimate S.E. } & \text { C.R. P Label } \\ .249 .034 & 7.229 * * * \\ 1.957 .377 & 5.194 * * * \\ .000 .000 & -4.621 * * * \\ -2.585 .518 & -4.996 * * * \\ -5.424 .388 & -13.993 * * * \\ .051 .007 & 7.690 * * *\end{array}$

Base models are created to demonstrate direct relationships between the main predictors (see Figure 6 below). 
Figure 6 The Base Path Model for Economic Signal Performance Using ROA and Standardized Regression Weights.

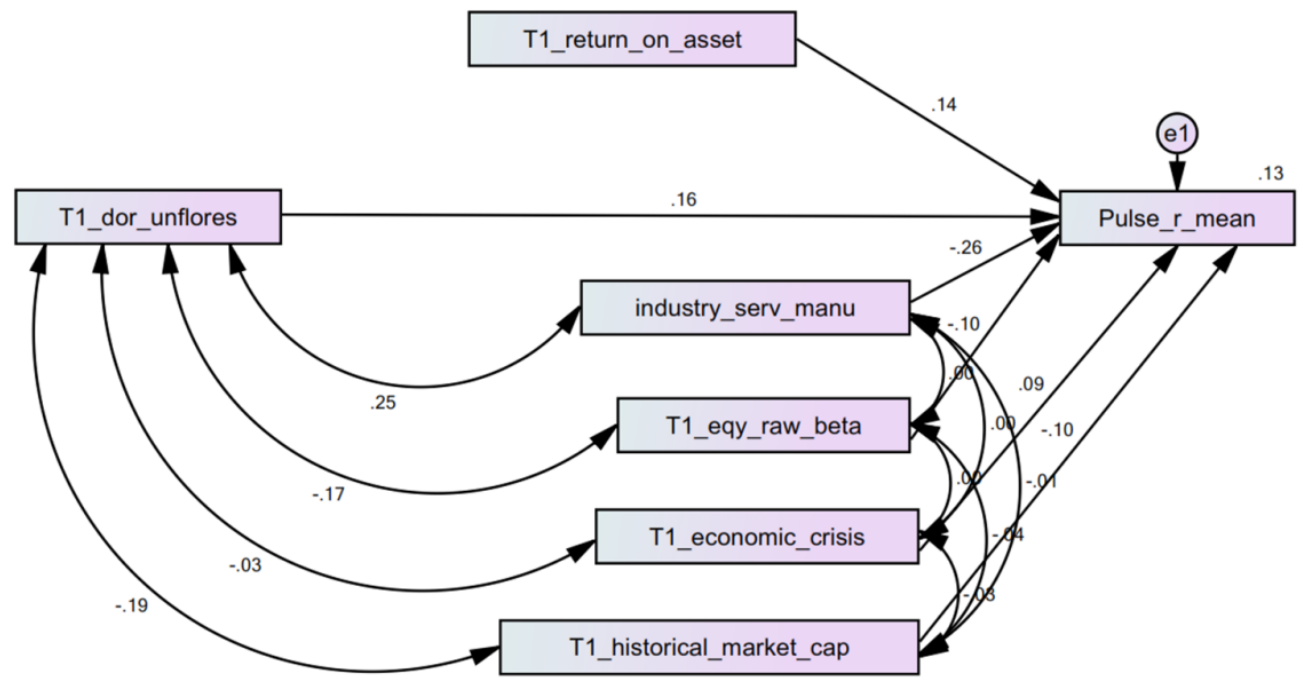

A path model was then created including the mediating pathway between regionalization, ROA, and firm reputation (see Figure 7) and then tested for significant relationships (see Table 11) and improvement in model fit using the chi-square difference test.

Figure 7 The Mediation Path Model for Economic Signal Performance Using ROA and Standardized Regression Weights.

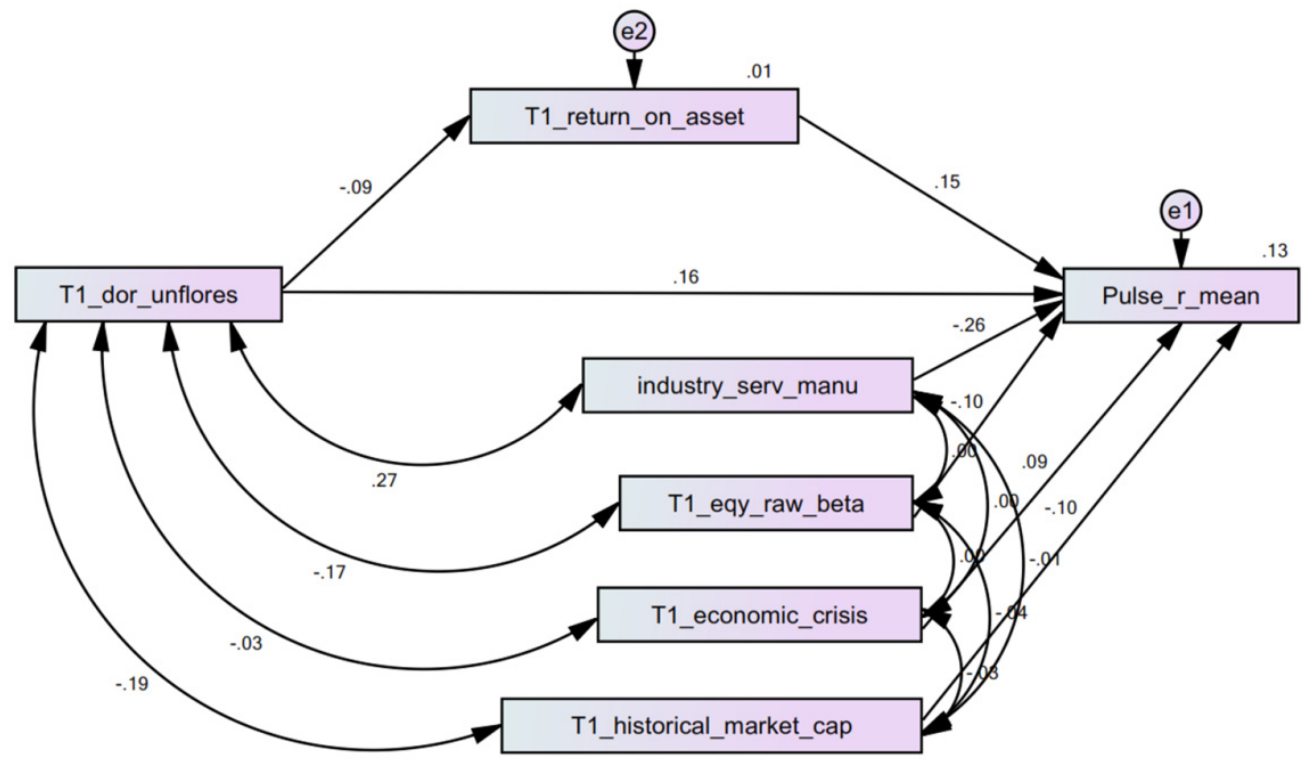


Table 11 Model for Economic Mediation with Unstandardized Regression Weights and Significance Levels.

Regression Weights: (Group number 1 - Default model)

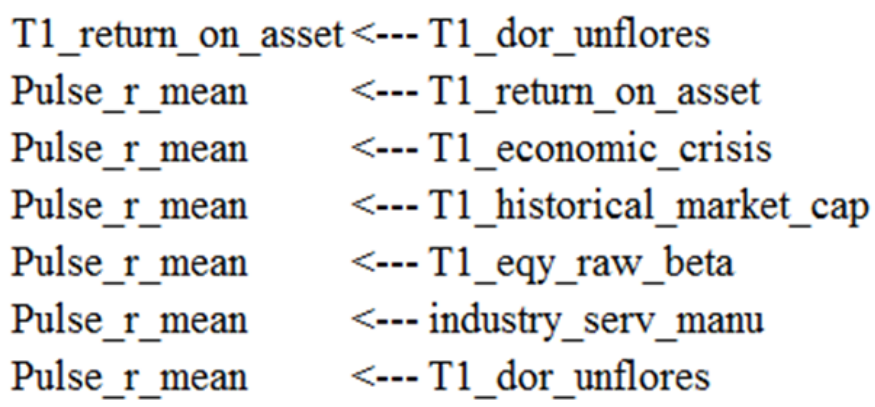

T1_return_on_asset<--- T1_dor_unflores

Pulse_r_mean <---T1_return_on_asset

Pulse_r_mean <--- T1_economic_crisis

Pulse_r_mean <--- T1_historical_market_cap

Pulse_-

Pulse_r_mean
Estimate S.E. C.R. P Label

$-.017 .004-4.779 * * *$

$.254 .035 \quad 7.358 * * *$

$1.958 .377 \quad 5.199 * * *$

$.000 .000-4.647 * * *$

$-2.573 .517-4.980 * * *$

$-5.418 .389-13.931 * * *$

$.051 .007 \quad 7.759 * * *$

The base relationship between regionalization and firm reputation is positive and significant $(\mathrm{p}<.001)$ indicating support for hypothesis 1 .

Hypothesis 2 argued that the relationship between regionalization and firm reputation would be mediated by economic signal performance. When introduced the results indicated a significant $(\mathrm{p}<.001)$ negative relationship between regionalization and economic signal performance using ROA. There remained a significant $(\mathrm{p}<.001)$ positive relationship between ROA and reputation as well as regionalization and reputation indicating that partial mediation may exist. To confirm a chi-square difference test was performed using appropriate model statistics for the base model and mediation model with results indicating a significant improvement in model fit (see Table 12). Thus, results support hypothesis 2 as a partially-mediated relationship. 
Table 12 Model fit indicators and Results of Difference Test Economic Mediation.

\begin{tabular}{|l|l|}
\hline Economic Signal Base Model : & Economic Signal Mediation Model: \\
\hline Minimum was achieved & Minimum was achieved \\
Chi-square $=859.598$ & Chi-square $=837.603$ \\
Degrees of freedom $=5$ & Degrees of freedom $=4$ \\
\hline $\begin{array}{l}\text { Difference Test: } \text { Chi-squares } 859-837=22 ; \text { Degrees of Freedom } 5-4=1 \\
\text { Significant model improvement }(\mathrm{p}<.001)\end{array}$ \\
\hline
\end{tabular}

Hypothesis 3 argued that the relationship between regionalization and firm reputation would be mediated by environmental signal performance. Following the same approach as used in hypothesis 2 we first established a base model wherein a significant relationship $(\mathrm{p}<.001)$ was established between regionalization and firm reputation as well as environmental signal performance and firm reputation (see Table 13).

Table 13 Base Model for Environmental Signal Performance with Unstandardized Regression Weights and Significance Levels.

\section{Regression Weights: (Group number 1 - Default model)}

$\begin{array}{lrrr} & \text { Estimate S.E. } & \text { C.R. } & \text { P Label } \\ \text { Pulse_r_mean<--- T1_dor_unflores } & .043 .007 & 6.469 * * * \\ \text { Pulse_r_mean<--- T1_environ_disclosure_score } & -.096 .014 & -6.987 * * * \\ \text { Pulse_r_mean<--- industry_serv_manu } & -6.483 .388 & -16.719 * * * \\ \text { Pulse_r_mean<--- T1_eqy_raw_beta } & -3.719 .516 & -7.204 * * * \\ \text { Pulse_r_mean <--- T1_economic_crisis } & 2.127 .377 & 5.643 * * * \\ \text { Pulse_r_mean <--- T1_historical_market_cap } & .000 .000 & -2.664 .008\end{array}$

While results showed a significant $(\mathrm{p}<.001)$ negative relationship between environmental signal generation and firm reputation, the results remained consistent and positive between regionalization and firm reputation (See figure 8). 
Figure 8 The Base Path Model for Environmental Signal Performance Using ESG from Bloomberg and Standardized Regression Weights.

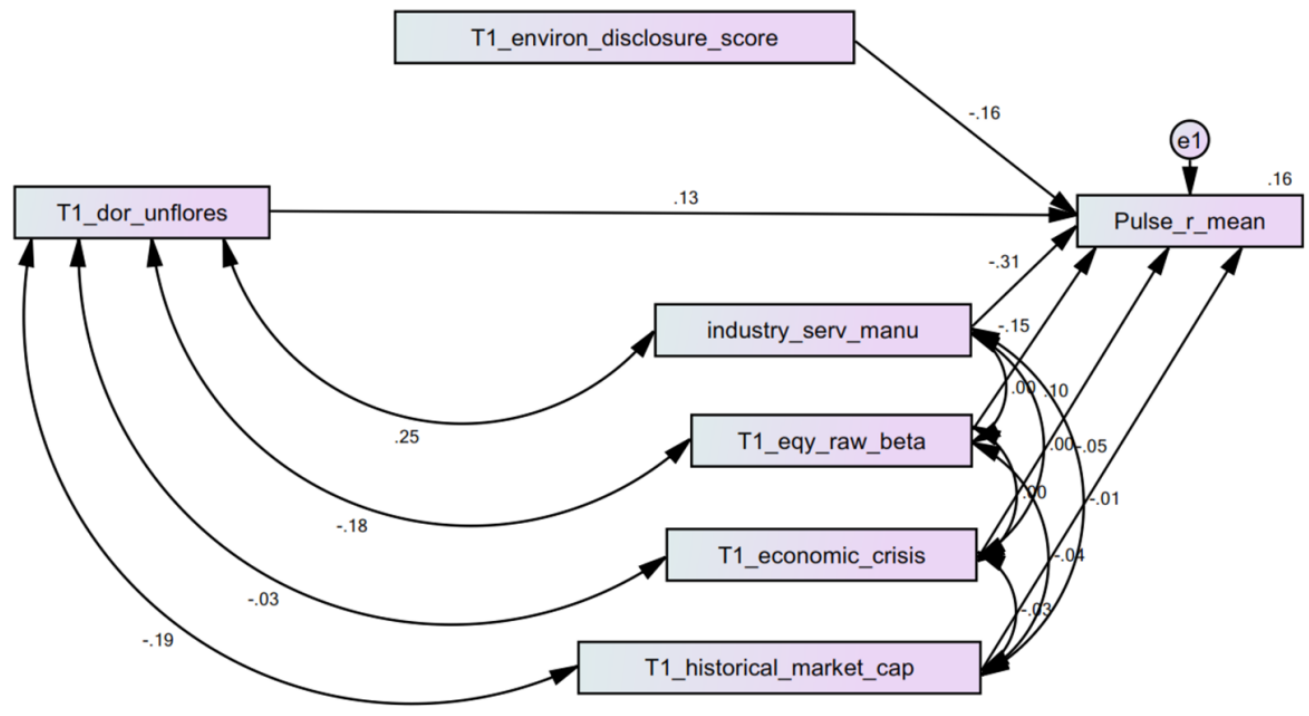

A path model was then created including the mediating pathway between regionalization, environmental signal performance, and firm reputation (see figure 9) and then tested for significant relationships (see Table 14) and improvement in model fit using the chi-square difference test.

Figure 9 The Mediation Path Model for Environmental Signal Performance Using ESG from Bloomberg and Standardized Regression Weights.

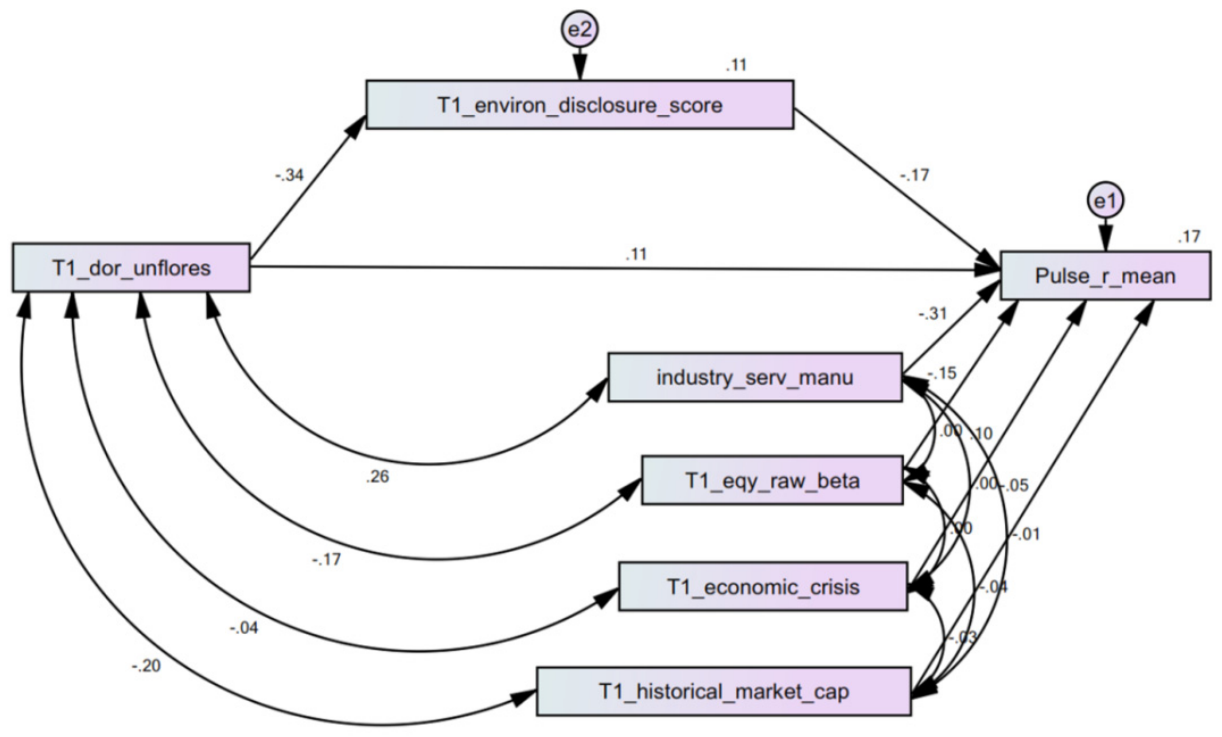


Table 14 Base Model for Environmental Signal Performance with Unstandardized Regression Weights and Significance Levels.

Regression Weights: (Group number 1 - Default model)

T1_environ_disclosure_score <--- T1_dor_unflores

Estimate S.E. C.R. P Label

Pulse_r_mean

$<--$ T1_dor_unflores

$-.178 .012-15.364 * * *$

Pulse_r_mean

$<---$ T1_environ_disclosure_score

Pulse_r_mean

$<--$ industry_serv_manu

$.035 .007 \quad 4.966 * * *$

Pulse_r_mean

<--- T1_eqy_raw_beta

$-.100 .015-6.874 * * *$

Pulse_r_mean

<--- T1_economic_crisis

$-6.503 .388-16.751 * * *$

Pulse_r_mean

$<--$ T1_historical_market_cap

$-3.741 .516-7.256 * * *$

$2.183 .377 \quad 5.789 * * *$

$\begin{array}{lll}.000 .000 & -2.563 .010\end{array}$

When introduced the results indicated a significant $(\mathrm{p}<.001)$ negative relationship between regionalization and environmental signal performance using environmental disclosure score. The base model relationships were consistent and remained significant indicating that partial mediation may exist. To confirm a chi-square difference test was performed using appropriate model statistics for the base model and mediation model with results indicating a significant improvement in model fit (see Table 15).

Table 15 Model Fit Indicators and Results of Difference Test Environmental Mediation.

\begin{tabular}{|l|l|}
\hline Environmental Signal Base Model : & Environmental Signal Mediation Model: \\
\hline Minimum was achieved & Minimum was achieved \\
Chi-square $=355.696$ & Chi-square $=156.202$ \\
Degrees of freedom $=5$ & Degrees of freedom $=4$ \\
\hline $\begin{array}{l}\text { Difference Test: Chi-squares } 355-156=199 ; \text { Degrees of Freedom } 5-4=1 \\
\text { Significant model improvement }(\mathrm{p}<.001)\end{array}$
\end{tabular}

Thus, results support hypothesis 3 as a partially-mediated relationship by environmental performance. 
Hypothesis 4 argued that the relationship between regionalization and firm reputation would be mediated by social signal performance. Following the same approach as used in hypotheses $2 \& 3$ we first established a base model wherein a significant relationship $(\mathrm{p}<.001)$ was established between regionalization and firm reputation as well as social signal performance and firm reputation (see Table 16).

Table 16 Showing Base Model for Social Signal Performance with Unstandardized Regression Weights and Significance Levels.

\section{Regression Weights: (Group number 1 - Default model)}

Pulse_r_mean <--- T1_dor_unflores

Pulse_r_mean $<---$ industry_serv_manu

Pulse_r_mean <--- T1_eqy_raw_beta

Pulse_r_mean $<---T 1$ economic_crisis

Pulse_r_mean <--- T1_historical_market_cap

Pulse_r_mean <--- T1_social_disclosure_score

$$
\begin{aligned}
& \text { Estimate S.E. C.R. P Label } \\
& \begin{array}{lll}
.045 .007 & 6.797 * * *
\end{array} \\
& -6.266 .389-16.121 * * * \\
& -3.778 .518-7.298 * * * \\
& 2.002 .378 \quad 5.300 * * * \\
& .000 .000-3.030 .002 \\
& \begin{array}{lll}
-.067 .012 & -5.604 * * *
\end{array}
\end{aligned}
$$

While results showed a significant $(\mathrm{p}<.001)$ negative relationship between social signal generation and firm reputation, the results remained consistent and positive between regionalization and firm reputation (See Figure 10). 
Figure 10 The Base Path Model for Social Signal Performance Using ESG from Bloomberg and Standardized Regression Weights.

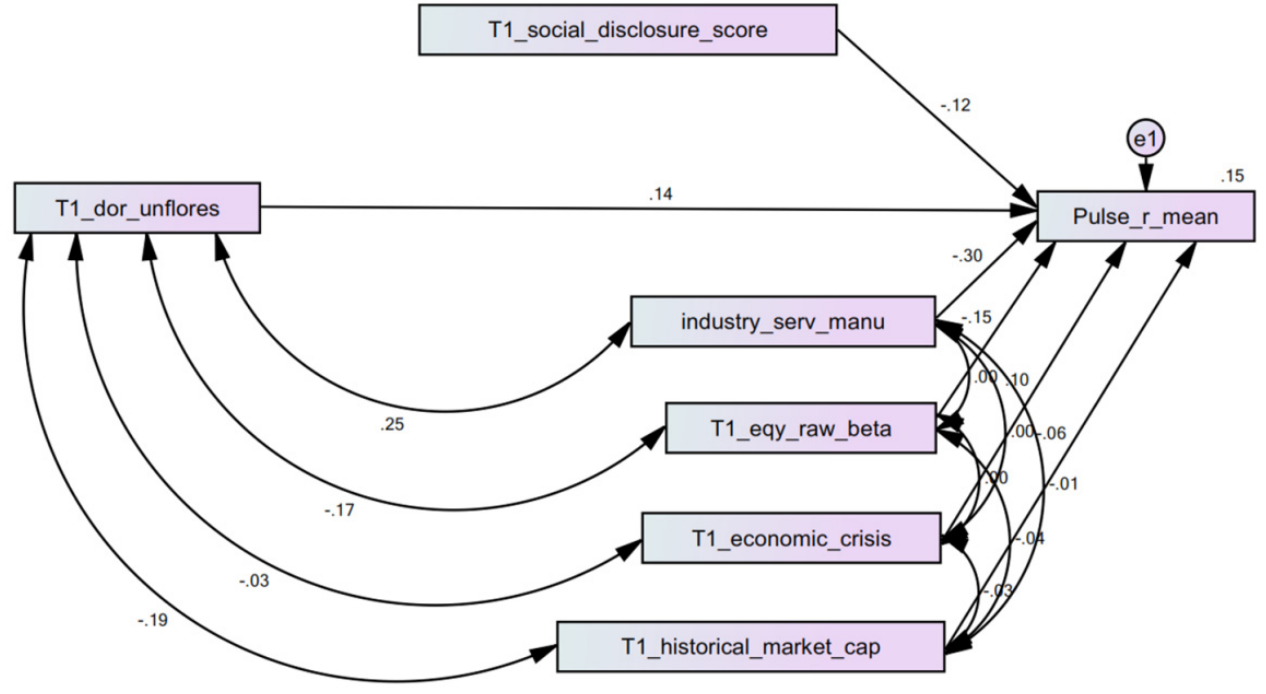

A path model was then created including the mediating pathway between regionalization, social signal performance, and firm reputation (see figure 11) and then tested for significant relationships (see Table 17) and improvement in model fit using the chi-square difference test.

Figure 11 The Mediation Path Model for Social Signal Performance Using ESG from Bloomberg and Standardized Regression Weights.

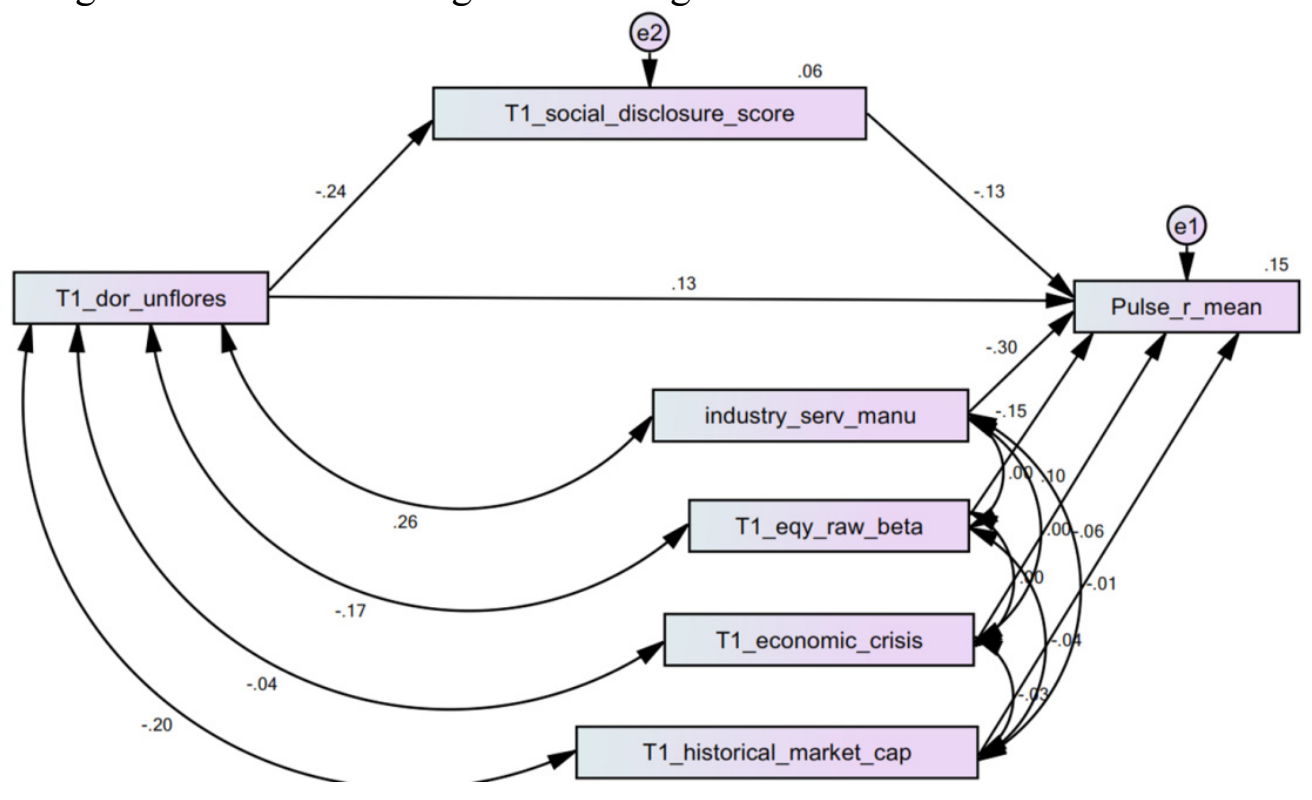


Table 17 Mediation Model for Environmental Signal Performance with Unstandardized Regression Weights and Significance Levels.

\section{Regression Weights: (Group number 1 - Default model)}

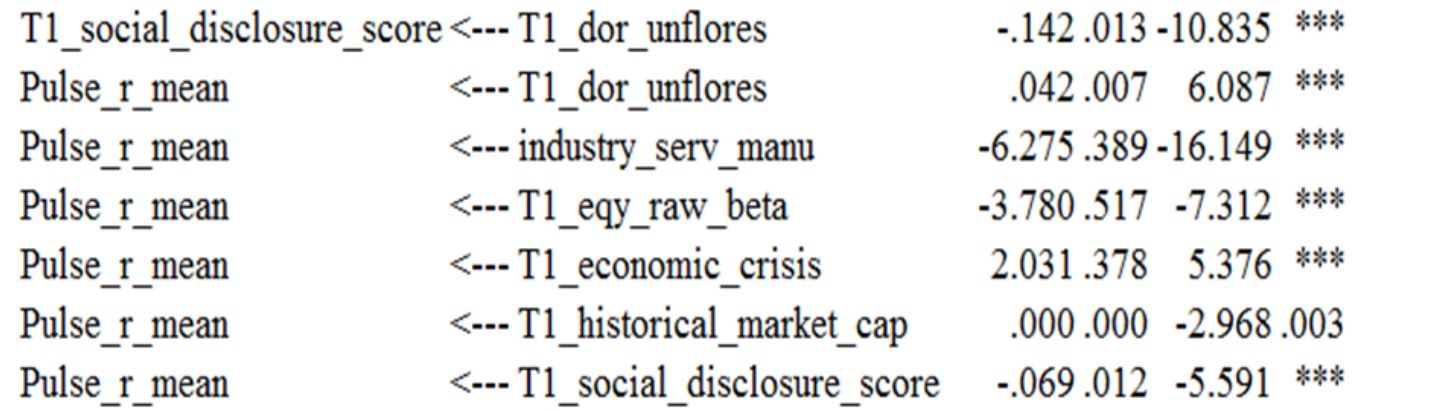

When introduced the results indicated a significant $(\mathrm{p}<.001)$ negative relationship between regionalization and social signal performance using social disclosure score. The base model relationships were consistent and remained significant indicating that partial mediation may exist. To confirm a chi-square difference test was performed using appropriate model statistics for the base model and mediation model with results indicating a significant improvement in model fit (see Table 18).

Table 18 Model Fit Indicators and Results of Difference Test Social Mediation

\begin{tabular}{|l|l|}
\hline Social Signal Base Model : & Social Signal Mediation Model: \\
\hline Minimum was achieved & Minimum was achieved \\
Chi-square $=198.800$ & Chi-square $=93.004$ \\
Degrees of freedom $=5$ & Degrees of freedom $=4$ \\
\hline $\begin{array}{l}\text { Difference Test: Chi-squares } 198-93=105 ; \text { Degrees of Freedom } 5-4=1 \\
\text { Significant model improvement }(\mathrm{p}<.001)\end{array}$ \\
\hline
\end{tabular}

Thus, results support hypothesis 3 as a partially-mediated relationship by environmental performance. 


\section{DISCUSSION}

Alternative mediation tests were conducted including simultaneously mediation of all three "Triple Bottom-line" variables so that I may test for dominance of any one mediator, as is likely with the financial performance measures. Similar to the prior approach to exploring single variable mediation all variables were introduced in a base model and found to possess significant $(\mathrm{p}<.001)$ relationships with firm reputation with the exception of social disclosure which was significant at $(\mathrm{p}<.05)$ (See Table 19).

Table 19 Full Base Model for Economic, Environmental, and Social Signal Performance with Unstandardized Regression Weights and Significance Levels.

Regression Weights: (Group number 1 - Default model)

Pulse_r_mean <--- T1_dor_unflores

Pulse_r_mean <--- industry_serv_manu

Pulse_r_mean<--- T1_eqy_raw_beta

Pulse_r_mean <--- T1_economic_crisis

Pulse_r_mean <--- T1_historical_market_cap

Pulse_r_mean <--- T1_social_disclosure_score

Pulse_r_mean<--- T1_return_on_asset

Pulse_r_mean <--- T1_environ_disclosure_score

$\begin{array}{rr}\text { Estimate S.E. } & \text { C.R. P Label } \\ .042 .007 & 6.454 * * * \\ -5.720 .385 & -14.867 * * * \\ -2.706 .513 & -5.275 * * * \\ 2.328 .374 & 6.227 * * * \\ .000 .000 & -4.064 * * * \\ -.024 .012 & -2.044 .041 \\ .240 .034 & 7.042 * * * \\ -.075 .014 & -5.517 * * *\end{array}$

A path model was then created including the mediating pathway between regionalization, economic, environmental, and social signal performance, and firm reputation (see Figure 12) and then tested for significant relationships (see Table 20) and improvement in model fit using the chi-square difference test. 
Figure 12 The Mediation Path Full Model for Economic, Environmental, and Social Signal Performance Using ESG from Bloomberg and Standardized Regression Weights.

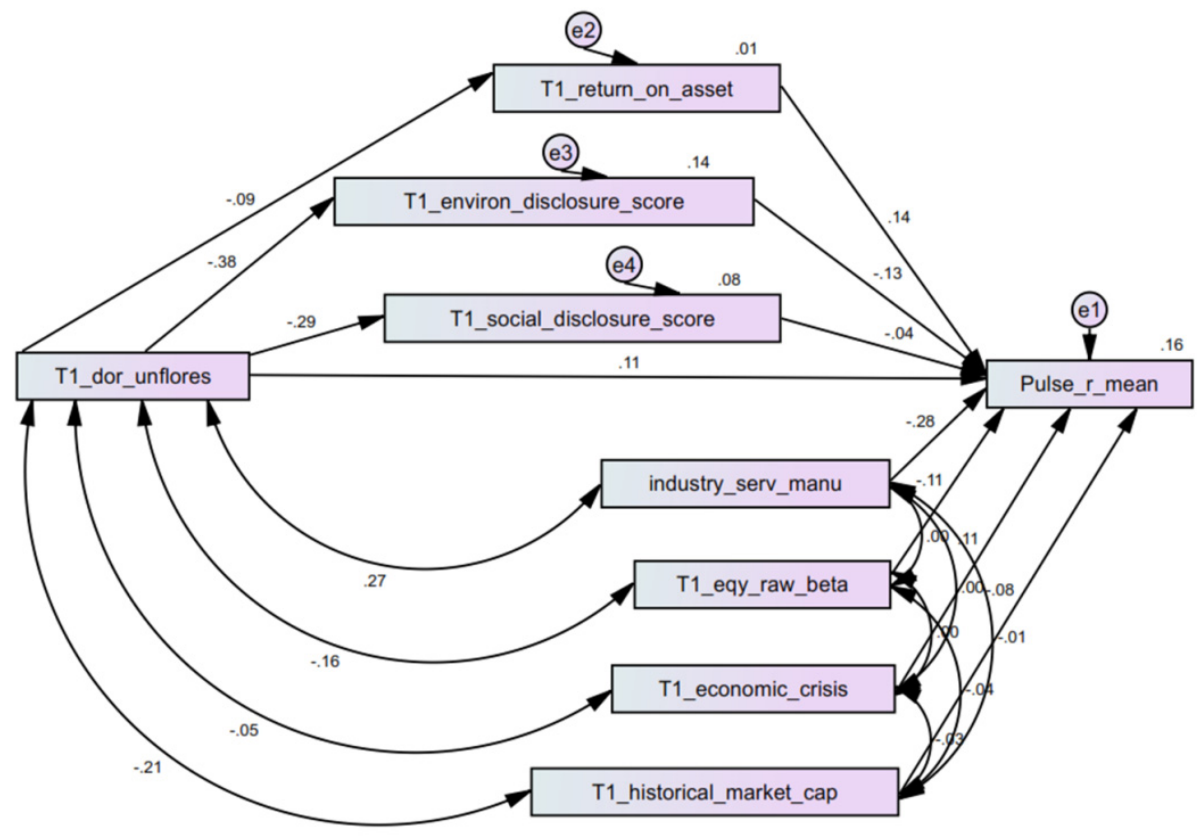

Table 20 Showing Mediation Full Model for Economic, Environmental, and Social Signal Performance with Unstandardized Regression Weights and Significance Levels.

Regression Weights: (Group number 1 - Default model)

$\begin{array}{ll}\text { T1_return_on_asset } & <---\mathrm{T} 1 \text { _dor_unflores } \\ \text { T1_social_disclosure_score } & <---\mathrm{T} 1 \text { _dor_unflores } \\ \text { T1_environ_disclosure_score }<---\mathrm{T} 1 \text { _dor_unflores } \\ \text { Pulse_r_mean } & <---\mathrm{T} 1 \text { _dor_unflores } \\ \text { Pulse_r_mean } & <--- \text { industry_serv_manu } \\ \text { Pulse_r_mean } & <---\mathrm{T} 1 \text { _eqy_raw_beta } \\ \text { Pulse_r_mean } & <--\mathrm{T} 1 \text { _economic_crisis } \\ \text { Pulse_r_mean } & <---\mathrm{T} 1 \text { historical_market_cap } \\ \text { Pulse_r_mean } & <---\mathrm{T} 1 \text { _social_disclosure_score } \\ \text { Pulse_r_mean } & <---\mathrm{T} 1 \text { return_on_asset } \\ \text { Pulse_r_mean } & <---\mathrm{T} 1 \text { environ_disclosure_score }\end{array}$

$\begin{array}{rrl}\text { Estimate S.E. } & \text { C.R. } & \text { P Label } \\ -.016 .003 & -4.457 & * * * \\ -.170 .013 & -13.538 & * * * \\ -.196 .011 & -17.538 & * * * \\ .036 .007 & 4.755 & * * * \\ -5.740 .386 & -14.870 & * * * \\ -2.719 .511 & -5.319 & * * * \\ 2.378 .374 & 6.354 & * * * \\ .000 .000 & -3.945 & * * * \\ -.023 .012 & -1.871 .061 \\ .242 .034 & 7.056 & * * * \\ -.077 .015 & -5.244 & * * *\end{array}$

When introduced the results indicated a significant $(\mathrm{p}<.001)$ negative relationship between regionalization and both economic and environmental and signal performance using. However, the relationship between social disclosure and reputation becomes 
marginally significant $(\mathrm{p}<.10)$. The base model relationships were otherwise consistent and remained significant indicating that partial mediation may exist. To confirm a chisquare difference test was performed using appropriate model statistics for the base model and mediation model with results indicating a significant improvement in model fit (see Table 21).

Table 21 Showing Model Fit Indicators and Results of Difference Test for Mediation in Full Model.

\begin{tabular}{|l|l|}
\hline Full Base Model : & Full Mediation Model: \\
\hline Minimum was achieved & Minimum was achieved \\
Chi-square $=2517.795$ & Chi-square $=2133.110$ \\
Degrees of freedom $=18$ & Degrees of freedom $=15$ \\
\hline $\begin{array}{l}\text { Difference Test: Chi-squares } 2517-2133 \\
\text { Significant model improvement }(\mathrm{p}<.001)\end{array}$ & 384 ; Degrees of Freedom $18-15=3$ \\
\hline
\end{tabular}

Robustness checks were performed using alternative measures of regionalization including classifications of three regions (Rugman), four regions (Hitt), and six regions (Dunning). These classifications were based on various overlapping dimensions of geography, culture, and socioeconomic development. Results were fairly consistent across these classifications and in addition entropy measures following the approach of Qian and colleagues (2008) were also consistent.

Additional variables were introduced as controls such as the number of employees as an indicator of size and potential visibility, the industry globalization levels to address industry efficiency fit, and industry concentration to explore the need to develop reputation as an intangible asset and exposure to competition. These variables were mainly non-significant or were not as significant and yet highly related to control variables that were included (e.g., industry classification service or manufacturing was 
the most significant industry control so the others were omitted). Interestingly, while market capitalization appears to be significantly related to firm reputation, in accordance with arguments on visibility (Fombrun \& Shanley, 1990), the effect size and direction are negligible indicating that size and visibility can be good and bad which is similar to other research findings. Service firms are shown to have worse reputation scores than manufacturing which could be a result of the direct tie to the firm and personal nature of services allowing for more critical assessment and perhaps manufacturing firms have reputational assessments slightly mediated by the products they produce. Using a period fixed effect to represent the economic crisis; it appeared firms had higher reputations as a result of the economic crisis. While this result seems counterintuitive it may represent a direct effort by organizations to restore confidence in them and an attempt to create goodwill in order to compete in a tougher economy. Lastly, firm risk, or Beta, was negatively associated with firm reputation which is logical.

\section{Limitations \& Assumptions -}

There are several limitations associated with the analyses. First, causality is inferred and pathways determined by theoretical arguments. It is recognized that reputation is an important strategic asset which in itself can determine a firm's success and influence its strategic decision making (Dowling, 1986; Williams et al., 2005; Barney, 1991). Accordingly, reputation may influence a firm's internationalization patterns and impact its performance in a variety ways such that reverse causality or a causal loop might exist. We acknowledge this relationship as fundamentally important to need to study reputation as a vital firm asset; however, we ground our decisions in the Klein and colleagues (1978) characterization that corporate reputation is an outcome 
determined by firm behavior in the past and "the premium stream is then merely a normal rate of return on the "reputation," or "brand-name" capital created by the firm by these initial expenditures (Klein et al., 1978: 306)" As such it makes sense to view the relationships as we have. Additional analyses using autoregressive techniques to allow for the possibility that variables are correlated longitudinally reveal little variation and are consistent with the results of the SEM. In addition, in order to test for improvement of model fit covariance in the base model was restricted to the control variables and main predictor, regionalization, to ensure over specification of model and allow for consistency in comparison (i.e., mediating variables were not co-varied in the base models as they would become criterion variables in the mediation models). While this artificially restricts covariance and eliminates the possibility of multicollinearity as a result of the mediating variables, independent analyses revealed low variance inflation between variables such that any impact on prediction power would be minimal and err conservatively.

The variable selection for mediators allowed more flexibility on economic performance signals where return on equity and return on sales, inter alia, were also available and logical choices showing similar results. Environmental and social signal variables were limited and thus subject to criticism of convenience sampling. These variables did include several indicators commonly associated with the Global Reporting Initiative (GRI) and offered a comprehensive look at environmental and social performance which was adjusted by industry. In other words, while other options were available these measurements represented the most congruent measurements in accordance with our arguments, therefore providing the greatest content validity. The 
findings however are limited by reporting standards and therefore findings are subject to the limitations of our data.

\section{CONCLUSION}

In this essay we demonstrate that firms which internationalize have greater economic performance when they are less regional and this helps improve their reputation. Firms that internationalize and are more regional have lower environmental and social disclosure scores, which limit their damaging effects vis-à-vis reputation. Thus, firms that internationalize must consider that expanding regionally is better for its reputation overall, yet it can slightly inhibit economic performance and its favorable impact on reputation. Accordingly, firms should recognize that while regional diversification diminishes economic, environmental, and social performance indicators, the environmental and social indicators do not enhance reputation in their home market. 


\section{LIST OF REFERENCES}

\section{$\underline{\text { Chapter I References }}$}

Bausch, A. \& Krist, M., 2007. The Effect of Context-Related Moderators on the Internationalization-Performance Relationship: Evidence from Meta-Analysis, Management International Review, 47: pp. 319-347.

Bain, J. S. 1956. Barriers to New Competition. Cambridge Mass: Harvard University Press.

Berry, H. 2006. Leaders, laggards, and the pursuit of foreign knowledge. Strategic Management Journal, 27, 151-168.

Berry, H., Guillen, M. F., \& Zhou, N. 2010. An institutional approach to cross-national distance. Journal of International Business Studies, 41: 1460-1480.

Birkinshaw, J. M. \& A. J. Morrison. 1995. Configurations of strategy and structure in multinational subsidiaries, Journal of International Business Studies, 26(4):729-53.

Birkinshaw, J. M., A. J. Morrison, and J. Hulland 1995. 'Structural and competitive determinants of a global integration strategy', Strategic Management Journal, 16: 637655.

Buckley, P. 1988. The limits of explanation: Testing the internalization theory of the multinationial enterprise. Journal of International Business Studies, 19(2), 181-193.

Boddewyn, J.J., Halbrich, M.B., \& Perry, A.C. 1986. Service multinationals:

Conceptualization, measurement, and theory. Journal of International Business Studies, Fall: 41-58.

Buckley, P. J. \& Casson, M. C. 1976. The future of the multinational enterprise. London: Macmillan.

Buckley, P. J., \& Casson, M. C. 1998. Analyzing foreign market entry strategies; extending the internalization approach. Journal of International Business Studies, 29(3), 539-562.

Caves, R. E. and Porter, M. E. 1977. "From Entry Barriers to Mobility Barriers: Conjectural Decisions and Contrived Deterrence to New Competition." Quarterly Journal of Economics 91: 421-41.

Chandler, A. D. 1962. Strategy and structure: Chapters in the history of the American enterprise. Massachusetts Institute of Technology, Cambridge. 
Coase, R. H. 1937. The Nature of the Firm, Economica, 4(16): 386-405.

Collinson, S., \& Rugman, A. M. 2008. The regional nature of Japanese multinational business. Journal of International Business Studies, 39: 215-230.

Contractor, F. J., Kundu, S. K., \& Hsu, C. 2003. A three stage theory of international expansion: The link between multinationality and performance in the service sector. Journal of International Business Studies, 34:5-18.

Dunning, J. H. 1977. Trade, location of economic activity and the MNE: a search for an eclectic approach. In B. Olhin, P. Hesselborn, \& P. Wijkman (Eds.), The international allocation of economic activity: 395-418. London: MacMillan.

Dunning, J. H. 1981. International Production and the Multinational Enterprise. London: Allen \& Unwin.

Dunning, J. H. 1993. Multinational enterprises and the global economy. Wokingham, Berkshire: Addison Wesley.

Dunning, J. H. 1995. Reappraising the Eclectic Paradigm in an Age of Alliance Capitalism, Journal of International Business Studies, 26(3):461-491.

Dunning, J. H. 2009. Location and the multinational enterprise: A neglected factor? Journal of International Business Studies, 40:5-19.

Errunza, V. R. \& Senbet, L. W. 1984. International Corporate Diversification, Market Valuation, and Size- Adjusted Evidence. The Journal of Finance, 39(3): 28-30.

Flores, R.G. \& Aguilera, R.V. 2007. Globalization and location choice: An analysis of US multinational firms in 1980 and 2000. Journal of International Business Studies, 38(7):1187-1210.

Friedman, T. L. 2005. The world is flat: A brief history of the twenty-first century. New York: Farrar, Straus and Giroux.

Gatignon,H . \& E. Anderson. 1987. The multinational corporation's degree of control over foreign subsidiaries: An empirical test of a transaction cost explanation. Report *8703. Cambridge: Marketing Science Institute.

Gomes, L. K. \& Ramaswamy, K. 1999. An empirical examination of the form of the relationship between multinationality and performance. Journal of International Business Studies, 30(1): 173-188. 
Geringer, J. M., Beamish, P. W. \& daCosta, R. C. 1989. Diversification strategy and internationalization: implications for MNE Performance. Strategic Management Journal, 10(2): 109-119.

Ghemawat, P. 2001. Distance Still Matters-The Hard Reality of Global Expansion. Harvard Business Review, 137-146.

Goerzen A, Beamish PW. 2003. Geographic scope and multinational enterprise performance. Strategic Management Journal, 24(13): 1289-1306

Grant, R. M., Jammine, A. P. \& Thomas, H. 1988. Diversity, diversification and profitability among British manufacturing companies, 1972-1984. Academy Management Journal, 31: 771-801.

Hennart, Jean- François. 1982.Theory of Multinational Enterprise. Ann Arbor: University of Michigan Press.

Hennart Jean- François. 2007. The theoretical rationale for a multinationalityperformance relationship. Management International Review 47(3): 307-317.

Hennart, Jean-François 2011. "A theoretical assessment of the empirical literature on the impact of multinationality on performance", Global Strategy Journal, 1: 135-151

Hill, C. W. L. \& Hoskisson, R. E. 1987. Strategy and structure in the multiproduct firm. Academy of Management Review, 12: 331-341.

Hill, C. W., Hitt, M. A., \& Hoskisson, R. E. 1992. Cooperative versus competitive structures in related and unrelated diversified firms. Organization Science, 3(4), 501-521.

Hitt, M. A., Hoskisson, R. E., \& Kim, H. 1997. International diversification: Effects on innovation and firm performance in product-diversified firms. Academy of Management Journal, 40(4):767-798.

Hoskisson, R. E., Hitt, M. A., Wan, W. P., \& Yiu, D. (1999). Theory and research in strategic management: Swings of a pendulum. Journal of Management, 25 (3), 417-456.

Hout, T. M., Porter, M. E., \& Rudden, E. 1982. How global companies win out Graduate School of Business Administration, Harvard University.

Hymer, S. 1976. The international operations of national firms: a study of foreign direct investment. MIT.

Johanson, J., \& Vahlne, J. E. 1977. The Internationalization Process of the Firm-A Model of Knowledge Development and Increasing Foreign Market Commitments. Journal of International Business Studies, Spring-Summer, 23-32. 
Kirca, A. H., Hult, G. T. M., Deligonul, S. Z., Perryy, M. Z., and Cavusgil, S. T. A Multilevel Examination of the Drivers of Firm Multinationality: A Meta-Analysis. Journal of Management, Forthcoming.

Kirka, A. H., Hult, G. T. M., Roth, K., Cavusgil, S. T., Perry, M., Akdeniz, M. B., Deligonul, S., Mena, J. A., Pollitte, W. A., Hoppner, J. J., Miller, J. C., \& White, R.C. 2011. Firm-specific assets, multinationality, and financial performance: A meta-analytic review and theoretical integration. Academy of Management Journal, 54(1): 47-72.

Knickerbocker, F.T. 1973. Oligopolistic Reaction and Multinational Enterprise. Boston.

Kogut, B., 1991. "Joint Ventures and the Option to Expand and Acquire," Management Science, 37, 19-33.

Kogut, B., \& Singh, H. 1988. The effect of national culture on the choice of entry mode. Journal of International Business Studies, 411-432.

Kogut, B. \& Zander, U. 1993. Knowledge of the firm and the evolutionary theory of the multinational corporation. Journal of International Business Studies, 24: 625-645.

Kostova, T. \& Zaheer, S. 1999. Organizational legitimacy under conditions of complexity: The case of the multinational enterprise. Academy of Management Review, 24: 64-81.

Kostova, T. 1999. Transnational transfer of strategic organizational practices: A contextual perspective. Academy of Management Review, 24: 306-324.

Kostova, T. \& Roth, K. 2002. Adoption of an organizational practice by subsidiaries of multinational corporations: Institutional and relational effects. Academy of Management Journal, 45: 213-233.

Lu, J.W., \& Beamish, P.W. 2004. International diversification and firm performance: The S-curve hypothesis. Academy of Management Journal, 47(4):598-609.

Markides, C., P. Williamson. 1994. Related diversification, core competencies and corporate performance. Strategic Management Journal. 15(Summer Special Issue) 149167.

Michel, A. \& Shaked, I. 1986. Multinational corporations vs. domestic corporations: financial performance and characteristics. Journal of International Business Studies, 17(3): 89-101.

Morck, R. and Yeung, B. (1991) 'Why investors value multi-nationality', Journal of Business 64(20): 165-187. 
Ohmae, K. 1985. Triad Power: The Coming Shape of Global Competition, Free Press: New York.

Osterberg, D., \& Ajami, F. 1971 "The Multinational Corporation: Expanding the Frontiers of World Politics," Journal of Conflict Resolution, 25: 461-468.

Porter, M. E. 1979. How competitive forces shape strategy Harvard Business Review.

Porter, Michael E. 1980. Competitive strategy. New York: Free Press.

Qian, G. 1997. Assessing product-market diversification of US firms. Management International Review. 37(2):127-149.

Qian, G., Khoury, T. A., Peng, M. W., \& Qian, Z. 2010. The performance implications of intra- and inter- regional geographic diversification, Strategic Management Journal, 31:1018-1030.

Qian, G., Li, L., Li. J., \& Qian, Z. 2008. Regional diversification and firm performance. Journal of International Business Studies, 39:197-214.

Ramaswamy, K., Kroeck, K. G., \& Renforth, W. 1996. Measuring the degree of internationalization of a firm: A comment. Journal of International Business Studies, 27(1):167-177.

Ronen, S., \& Shenkar, O. 1985. Clustering countries on attitudinal dimensions: A review and synthesis. Academy of Management Review, 10(3):435-454.

Roth, K., \& Morrison, A. J. 1992. Implementing global strategy: Characteristics of global subsidiary mandates. Journal of International Business Studies, , 715-735.

Rugman, A. M. 1986. New Theories of the Multinational Enterprise: An Assessment of Internalization Theory. Bulletin of Economic Research, 38(2):101-18.

Rugman, A. M. 2000. The end of globalization. London: Random House Business.

Rugman, A. M. \& Oh, C. H. 2010. Does the regional nature of multinationals affect the multinationality and performance relationship? International Business Review, 19:479488.

Rugman, A. M. \& Verbeke, A. 2004. Perspective on regional and global strategies of multinational enterprises. Journal of International Business Studies, 35(1):3-18. 
Rugman, A. M., \& Verbeke, A. 2007. Liabilities of foreignness and the use of firm-level versus country-level data: A response to Dunning et al. 2007. Journal of International Business Studies, 38(1): 200-205.

Ruigrok, W., \& Wagner, H. 2003. Internationalization and performance: an organizational learning perspective. Management International Review, 43:63-83.

Rumelt, R. (1974), Strategy, Structure, and Economic Performance, Cambridge, MA: Harvard University Press.

Siddharthan, N.S., \& Lall, S. 1982. Recent growth of the largest US multinationals. Oxford Bulletin of Economic Statistics, 44:1-13.

Stevens, M. J. \& Bird, A. 2004. On the myth of believing that globalization is a myth: or the effects of misdirected responses on obsolescing an emergent substantive discourse. Journal of International Management, 10(4): 501-510.

Stopford, J.M. and Wells, L.T. (1972) Managing the Multinational Enterprise, Basic Books: New York.

Sullivan D. 1994. Measuring the degree of internationalization of a firm. Journal of International Business Studies, 25(2): 325-342.

Sullivan, D. and Bauerschmidt, A. (1990) 'Incremental internationalization: a test of Johanson and Vahlne's thesis', Management International Review, 30(1): 19-30.

Thomas, D. E., \& Eden, L. 2004. What is the shape of the multinationality-performance relationship? The Multinational Business Review, 12: 89-110.

Tihanyi, L., Griffith, D. A. \& Russell, C.J. 2005. 'The effect of cultural distance on entry mode choice, international diversification, and MNE performance: a meta-analysis', Journal of International Business Studies, 36(3): 270-283.

Verbeke, A., \& Brugman, P. 2009. Triple-testing the quality of multinationalityperformance research: An internalization theory perspective. International Business Review, 18:265-275.

Vernon, R. 1966. International Investment and International Trade in the Product Life Cycle. Quarterly Journal of Economics, 80: 190-207.

Vernon, R. 1971. Sovereignty at bay: The multinational spread of US enterprises. New York: Basic.

Wiersema M, Bowen H. 2011. The relationship between international diversification and firm performance: why it remains a puzzle. Global Strategy Journal 1(1/3). 
Wilkins, M. 1970. The emergence of multinational enterprise: American business abroad, from the Colonial era to 1914. Cambridge, Mass: Harvard University Press.

Williamson, O. E. 1975. Markets and hierarchies: Analysis and antitrust implications. New Yory: Free Press.

World Bank. 1995. World development report: Workers in a dynamic world:

transforming institutions, growth, and quality of life. New York: Oxford University Press.

Yang, Y., \& Driffield, N. 2012. Multinationality-Performance Relationship: A Metaanalysis, The Multinational Business Review, 52: 23-47.

Zaheer, S. 1995. Overcoming the liabilities of foreignness. Academy of Management Journal, 38(2): 341-363.

\section{$\underline{\text { Chapter II References }}$}

Bain, J. S. 1956. Barriers to New Competition. Cambridge Mass: Harvard University Press.

Barney, J. B. 1991. Firms resources and sustained competitive advantage. Journal of Management, 17(1):99-120.

Birkinshaw, J. M., A. J. Morrison, and J. Hulland 1995. 'Structural and competitive determinants of a global integration strategy', Strategic Management Journal, 16: 637655.

Boyne, G. A. 2003. Sources of Public Service Improvement: A Critical Review and Research Agenda, Journal of Public Administration Research and Theory, 13: 367-394

Campbell, J. L. 2007. Why would corporations behave in socially responsible ways? An institutional theory of corporate social responsibility. Academy of Management Review, 32: 946-967.

Chakravarthy, B. 1986. Measuring strategic performance. Strategic Management Journal, 6: 437-458.

Collinson, S., \& Rugman, A. M. 2008. The regional nature of Japanese multinational business. Journal of International Business Studies, 39: 215-230.

Contractor, F. J., Kundu, S. K., \& Hsu, C. 2003. A three stage theory of international expansion: The link between multinationality and performance in the service sector. Journal of International Business Studies, 34:5-18. 
Dunning, J. H. 2009. Location and the multinational enterprise: A neglected factor? Journal of International Business Studies, 40:5-19.

Elkington, J. 2004. Enter the Triple Bottom Line. in Adrian Henriques and Julie Richardson (eds) The Triple Bottom Line: does it all add up. EarthScan: London UK.

Flores, R.G. \& Aguilera, R.V. 2007. Globalization and location choice: An analysis of US multinational firms in 1980 and 2000. Journal of International Business Studies, 38(7):1187-1210.

Fombrun, C.J., \& Shanley, M. 1990. What's in a name? Reputation building and corporate strategy. Academy of Management Journal, 33:233-258.

Freeman, R. E. 1984. Strategic management: A stakeholder approach. Boston: Pitman.

Friedman, M. 1970. The social responsibility of business is to increase its profits. New York Times Magazine. September 13 1970, pp. 122-126.

Hall, R. 1992. The strategic analysis of intangible resources. Strategic Management Journal, 13: 135-144.

Haugh, H.M. and Talwar, A. 2010. How Do Corporations Embed Sustainability Across the Organization? The Academy of Management Learning and Education, Vol. 9, No. 3. (Sept.), pp. 384-396.

Hennart, Jean-François 2011. "A theoretical assessment of the empirical literature on the impact of multinationality on performance", Global Strategy Journal, 1: 135-151

Hill, C. W. L. \& Hoskisson, R. E. 1987. Strategy and structure in the multiproduct firm. Academy of Management Review, 12: 331-341.

Hitt, M. A., Hoskisson, R. E., \& Kim, H. 1997. International diversification: Effects on innovation and firm performance in product-diversified firms. Academy of Management Journal, 40(4):767-798.

Hoskisson, R. E., Hitt, M. A., Wan, W. P., \& Yiu, D. (1999). Theory and research in strategic management: Swings of a pendulum. Journal of Management, 25 (3), 417-456.

King, A.A., Shaver, J.M. 2001. Are aliens green? Assessing foreign establishments' environmental conduct in the United States. Strategic Management Journal, 22(11): 1069-1085.

Kirka, A. H., Hult, G. T. M., Roth, K., Cavusgil, S. T., Perry, M., Akdeniz, M. B., Deligonul, S., Mena, J. A., Pollitte, W. A., Hoppner, J. J., Miller, J. C., \& White, R.C. 
2011. Firm-specific assets, multinationality, and financial performance: A meta-analytic review and theoretical integration. Academy of Management Journal, 54(1): 47-72.

Kogut, B. \& Zander, U. 1993. Knowledge of the firm and the evolutionary theory of the multinational corporation. Journal of International Business Studies, 24: 625-645.

Lu, J.W., \& Beamish, P.W. 2004. International diversification and firm performance: The S-curve hypothesis. Academy of Management Journal, 47(4):598-609.

Ohmae, K. 1985. Triad Power: The Coming Shape of Global Competition, Free Press: New York.

Prater, E.; Biehl, M. \& Smith, M. A. 2001. International supply chain agility: Tradeoffs between flexibility and uncertainty. International Journal of Operations and Production Management, 21 (5/6), 823-839.

Qian, G., Khoury, T. A., Peng, M. W., \& Qian, Z. 2010. The performance implications of intra- and inter- regional geographic diversification, Strategic Management Journal, 31:1018-1030.

Qian, G., Li, L., Li. J., \& Qian, Z. 2008. Regional diversification and firm performance. Journal of International Business Studies, 39:197-214.

Roberts P. W. \& Dowling G. R. 2002. Corporate reputation and sustained superior financial performance. Strategic Management Journal, 23: 1077-1093.

Rugman, A. M. 2000. The end of globalization. London: Random House Business.

Rugman, A. M. \& Oh, C. H. 2010. Does the regional nature of multinationals affect the multinationality and performance relationship? International Business Review, 19:479488.

Rugman, A. M., \& Verbeke, A. 2007. Liabilities of foreignness and the use of firm-level versus country-level data: A response to Dunning et al. 2007. Journal of International Business Studies, 38(1): 200-205.

Russo, M. V., and Fouts, P. A. 1997. A Resource-based Perspective on Corporate Environmental Performance and Profitability," Academy of Management Journal , 40: $534-59$.

Schneper W, Guillen M. 2004. Stakeholder rights and corporate governance: a crossnational study of hostile takeovers. Administrative Science Quarterly 49(June): 163-195.

Tallman, S., \& Li, J. 1996. Effects of international diver sity and product diversity on the performance of multinational firms. Academy of Management Journal, 39: 179-196. 
Vachon, S. and Klassen, R.D. 2006. Extending green practices across the supply chain: The impact of upstream and downstream integration. International Journal of Operations \& Production Manage

Yang, Y., \& Driffield, N. 2012. Multinationality-Performance Relationship: A Metaanalysis, The Multinational Business Review, 52: 23-47.

ment, 26 (7): 795-821.

\section{$\underline{\text { Chapter III References }}$}

Asher, H. 2004. Polling and the Public (6th ed.), CQ Press, Washington, DC.

Barney, J. B. 1991. Firms resources and sustained competitive advantage. Journal of Management, 17(1):99-120.

Baron, R. M., \& Kenny, D. A. 1986. The moderator-mediator variable distinction in social psychological research: Conceptual, strategic, and statistical considerations. Journal of Personality and Social Psychology, 51: 1173-1182.

Boyne, G. A. 2003. Sources of Public Service Improvement: A Critical Review and Research Agenda, Journal of Public Administration Research and Theory, 13: 367-394

Buckley, P. J. \& Casson, M. C. 1976. The future of the multinational enterprise. London: Macmillan.

Buckley, P. J., \& Casson, M. C. 1998. Analyzing foreign market entry strategies; extending the internalization approach. Journal of International Business Studies, 29(3), $539-562$.

Campbell, J. L. 2007. Why would corporations behave in socially responsible ways? An institutional theory of corporate social responsibility. Academy of Management Review, 32: 946-967.

Collinson, S., \& Rugman, A. M. 2008. The regional nature of Japanese multinational business. Journal of International Business Studies, 39: 215-230.

Connelly, B.L., Certo, S.T., Ireland R.D., and Reutzel, C.R. 2011. "Signaling Theory: A Review and Assessment”, Journal of Management Vol. 37 No. 1, pp. 39-67.

Deephouse, D.L. 2000. "Media reputation as a strategic resource: An integration of mass communication and resource-based theories", Journal of Management, Vol. 26, pp. 10911112. 
Deephouse, D.L., \& Carter, S.M. 2005. An examination of differences between organizational legitimacy and organizational reputation. Journal of Management Studies, 42(2):329-360.

Dierickx, I. \& Cool, K. 1989. "Asset Stock Accumulation and Sustainability of Competitive Advantage," Management Science, 33, 1504-1513.

DiMaggio, P.J., \& Powell, W.W. 1983. The iron cage revisited: Institutional isomorphism and collective rationality in organizational field. American Sociological Review, 48(2):147-160.

Elkington, J. 2004. Enter the Triple Bottom Line. in Adrian Henriques and Julie Richardson (eds) The Triple Bottom Line: does it all add up. EarthScan: London UK.

Flores, R.G. \& Aguilera, R.V. 2007. Globalization and location choice: An analysis of US multinational firms in 1980 and 2000. Journal of International Business Studies, 38(7):1187-1210.

Fombrun, C.J. 1996. Reputation: Realizing value from the corporate image. Boston: Harvard Business School.

Fombrun, C.J., \& Shanley, M. 1990. What's in a name? Reputation building and corporate strategy. Academy of Management Journal, 33:233-258.

Freeman, R. E. 1984. Strategic management: A stakeholder approach. Boston: Pitman.

Hall, R. 1992. The strategic analysis of intangible resources. Strategic Management Journal, 13: 135-144.

Hart, S. L. 1995. A natural resource-based view of the firm. Academy of Management Review, 20: 986-1014.

Haugh, H.M. and Talwar, A. 2010. How Do Corporations Embed Sustainability Across the Organization? The Academy of Management Learning and Education, Vol. 9, No. 3. (Sept.), pp. 384-396.

Hennart, Jean- François. 1982.Theory of Multinational Enterprise. Ann Arbor: University of Michigan Press.

Hennart, Jean-François 2011. "A theoretical assessment of the empirical literature on the impact of multinationality on performance", Global Strategy Journal, 1: 135-151

Highhouse, S., Lievens, F., \& Sinar, E.F. 2003. Measuring attraction to organizations. Educational and Psychological Measurement, 63:986. 
Hitt, M. A., Hoskisson, R. E., \& Kim, H. 1997. International diversification: Effects on innovation and firm performance in product-diversified firms. Academy of Management Journal, 40(4):767-798.

King, A.A., Shaver, J.M. 2001. Are aliens green? Assessing foreign establishments' environmental conduct in the United States. Strategic Management Journal, 22(11): 1069-1085.

Kirmani, A. and Rao, A.R. 2000. "No pain, no gain: A critical review of the literature on signaling unobservable product quality”, Journal of Marketing, Vol. 64 No. 2, pp. 66-79.

Klein, B., Crawford, R. G.; Alchian, A. A. 1978. Vertical Integration, Appropriable Rents, and the Competitive Contracting Process, Journal Law and Economics. 21: 297326.

Kostova, T. 1999. Transnational transfer of strategic organizational practices: A contextual perspective. Academy of Management Review, 24: 306-324.

Kostova, T. \& Zaheer, S. 1999. Organizational legitimacy under conditions of complexity: The case of the multinational enterprise. Academy of Management Review, 24: 64-81.

Love, G. E., \& Kraatz, M. 2009. Character, conformity or the bottom line? How and why downsizing affected corporate reputation. Academy of Management Journal, 52: 314335.

McGuire, J., Sundgren, A., \& Schneeweiss, T. 1988. Corporate social responsibility and firm financial performance. Academy of Management Journal, 31: 854-872.

Milgrom, P., \& Roberts, J. 1986. Relying on the information of interested parties. The RAND Journal of Economics, 17:18-32.

Newburry, W. 2010. Reputation and supportive behavior: Moderating impacts of foreignness, industry and local exposure. Corporate Reputation Review, 12(4):388-405.

Ohmae, K. 1985. Triad Power: The Coming Shape of Global Competition, Free Press: New York.

Parker, C.W. \& Lessig, V.P. 1981. Familiarity and its impact on consumer decision biases and heuristics. Journal of Consumer Research 8: 223-230.

Pfeffer. J., \& Salancik, G. 1978. The External Control of Organizations: A Resource Dependency Perspective, Harper and Row, New-York, 1978. 
Prater, E.; Biehl, M. \& Smith, M. A. 2001. International supply chain agility: Tradeoffs between flexibility and uncertainty. International Journal of Operations and Production Management, 21 (5/6), 823-839.

Qian, G., Li, L., Li. J., \& Qian, Z. 2008. Regional diversification and firm performance. Journal of International Business Studies, 39:197-214.

Rao, H. 1994. The social construction of reputation: Certification contests, legitimation, and the survival of organizations in the American automobile industry. Strategic Management Journal, 15: 29-44.

Roberts P. W. \& Dowling G. R. 2002. Corporate reputation and sustained superior financial performance. Strategic Management Journal, 23: 1077-1093.

Ross, S.A. 1977. "The determination of financial structure: The incentive signaling structure", Bell Journal of Economics, Vol. 8, pp. 23-40.

Ruef, M., \& Scott, W. R. 1998. A multidimensional model of organizational legitimacy: Hospital survival in changing institutional environments. Administrative Science Quarterly, 43: 877-904

Rugman, A. M. \& Oh, C. H. 2010. Does the regional nature of multinationals affect the multinationality and performance relationship? International Business Review, 19:479488.

Rugman, A. M. \& Verbeke, A. 2004. Perspective on regional and global strategies of multinational enterprises. Journal of International Business Studies, 35(1):3-18.

Russo, M. V., and Fouts, P. A. 1997. A Resource-based Perspective on Corporate Environmental Performance and Profitability," Academy of Management Journal , 40: 534-59.

Shenkar, O., \& Yuchtman-Yaar, E. 1997. Reputation, image, prestige, and goodwill: An interdisciplinary approach to organizational standing. Human Relations, 50(11):13611381.

Spence, M. 1973. “Job market signaling”, Quarterly Journal of Economics, Vol. 87, pp. 355-374.

Vachon, S. and Klassen, R.D. 2006. Extending green practices across the supply chain: The impact of upstream and downstream integration. International Journal of Operations \& Production Management, 26 (7): 795-821.

Williams, R. J., Schnake, M.E., \& Fredenberger, W. 2005. The impact of corporate strategy on a firm's reputation. Corporate Reputation Review, 8(3):187-197. 
Wilson, R. 1985. Reputations in games and markets. In, Roth, A. Game-theoretic models of bargaining. Cambridge University Press: Cambridge, U.K. 
VITA

\section{KEITH KELLEY}

Born, Laconia, New Hampshire

1996

High School Diploma

The Tilton School

Tilton, $\mathrm{NH}$

$1997-1998$

Entrepreneur - Lakes Region, NH

Commercial and Residential Painting Contractor

2001

B.S. Business Administration \& International Affairs

University of New Hampshire

Durham, NH

2001

Marketing Specialist Intern

Bottomline Technologies - Portsmouth, NH

$2002-2003$

Area Manager

Canadian Imperial Bank of Commerce - North Palm Beach, FL

2003-2005

Assistant Director of Admissions

Miami International University of Art \& Design - Miami, FL

2005-2007

Director of Admissions

Educating Hands - Miami, FL

2008

Masters of International Business

Florida International University

Miami, FL

2010-2013

Doctoral Candidate

Florida International University

Miami, FL

\section{PUBLICATIONS AND PRESENTATIONS}

Thams, Y., Kelley, K. \& Kundu, K. (2011). “A Strategic Leadership Perspective on the Internationalization of Emerging Market Multinationals" CIBER Working Paper Series.

Alvarado-Vargas, M. \& Kelley, K. (October, 2012). International Supply Chain Strategies in an Uncertain World: A Bullwhip Perspective, Strategic Management Society Conference. Prague, Czech Republic. 
Kelley, K. \& Newburry, W. (August, 2012). Service Characteristics and Firm Reputation: the Case of Telecom and Banking Industries, Academy of Management Conference, Boston, MA.

Kelley, K. (June, 2012). Spatial Relativism: Toward a Fine-Grained Approach for Capturing the Effect of Space (and time) in Multinationality and Performance Research, Academy of International Business Conference, Washington, D.C.

Kelley, K. \& Newburry, W. (April, 2012). Service characteristics, demographic characteristics, and individual assessments of firm reputation: the case of telecom and banking industries in Latin America, Academy of International Business Latin American Chapter, Miami, FL.

Zakaria, R., Thams, Y. \& Kelley, K. (August, 2011). Relational Typology of Institutional Distance and M\&A Transactions: A Two-Dimensional View, Academy of Management Conference, San Antonio, TX.

Alvarado-Vargas, M. \& Kelley, K. (June, 2011). International Supply Chain Strategies in an Uncertain World: A Bullwhip Perspective, Academy of International Business Conference, Nagoya, Japan.

Thams, Y., Kelley, K. \& Kundu, K. (June, 2011). A Strategic Leadership Perspective on the Internationalization of Emerging Market Multinationals, Academy of International Business Conference, Nagoya, Japan.

Kelley, K. (June, 2011). The efficacy of regional strategies: exploring alternative measures of regionalization and performance, Academy of International Business Doctoral Consortium, Nagoya, Japan.

Kelley, K. (May, 2011). Liabilities of Regionalization: Triad Regions and Emerging Markets, EUCE-CIBER John Hopkins University School of Advanced International Studies, Washington, D.C.

Kelley, K., Newburry, W. \& Yang, K. (March, 2011). Service characteristics, deregulation, and firm reputation: Comparing telecom and banking industries in Latin America, Strategic Management Society Special Conference, Rio de Janeiro.

Kelley, K., Thams, Y. Alavarado-Vargas, M. \& Yang, K. (September, 2010). Institutional Distance during Uncertainty: When foreignness isn't such a liability, Strategic Management Society Conference; Rome, Italy.

Kelley, K. (June, 2010). Liabilities of Regionalization and the Emerging Market Firm, Academy of International Business Conference; Rio de Janeiro, Brazil. 